NBER WORKING PAPER SERIES

\title{
RELIGION AND ECONOMIC GROWTH
}

\author{
Robert J. Barro \\ Rachel M. McCleary \\ Working Paper 9682 \\ http://www.nber.org/papers/w9682
}
NATIONAL BUREAU OF ECONOMIC RESEARCH 1050 Massachusetts Avenue
Cambridge, MA 02138
May 2003

This research was supported by grants from the National Science Foundation and the John Templeton Foundation. We have benefited from comments by Gary Becker, Francesco Caselli, Mark Chaves, Ed Glaeser, Charles Harper, Jason Hwang, Laurence Iannaccone, Greg Mankiw, James Montgomery, Thomas Osang, Robert Woodberry, and participants in several seminars and classes. The views expressed herein are those of the authors and not necessarily those of the National Bureau of Economic Research.

(C)2003 by Robert J. Barro and Rachel M. McCleary. All rights reserved. Short sections of text not to exceed two paragraphs, may be quoted without explicit permission provided that full credit including Cnotice, is given to the source. 
Religion and Economic Growth

Robert J. Barro and Rachel M. McCleary

NBER Working Paper No. 9682

May 2003

JEL No. O1, O4, Z1

\section{$\underline{\text { ABSTRACT }}$}

Empirical research on the determinants of economic growth has typically neglected the influence of religion. To fill this gap, we use international survey data on religiosity for a broad panel of countries to investigate the effects of church attendance and religious beliefs on economic growth. To isolate the direction of causation from religiosity to economic performance, we use instrumental variables suggested by our analysis of systems in which church attendance and beliefs are the dependent variables. The instruments are dummy variables for the presence of state religion and for regulation of the religion market, an indicator of religious pluralism, and the composition of religions. We find that economic growth responds positively to the extent of religious beliefs, notably those in hell and heaven, but negatively to church attendance. That is, growth depends on the extent of believing relative to belonging. These results accord with a perspective in which religious beliefs influence individual traits that enhance economic performance. The beliefs are, in turn, the principal output of the religion sector, and church attendance measures the inputs to this sector. Hence, for given beliefs, more church attendance signifies more resources used up by the religion sector.

Robert J. Barro

Department of Economics

Harvard University

Cambridge, MA 02138

and NBER

rbarro@harvard.edu
Rachel M. McCleary

Weatherhead Center for International

Affairs

Harvard University

Cambridge, MA 02138

mccleary@wcfia.harvard.edu 


\section{Introduction}

Previous research by economists has used the experience of a broad panel of countries to assess the determinants of economic growth—see, for example, Barro (1991, 2000) and Barro and Sala-i-Martin (2003, Ch. 12). This literature has isolated a number of variables that predict subsequent rates of economic growth. One general conclusion is that successful explanations of economic performance have to go beyond narrow measures of economic variables to encompass political and social forces. In particular, the empirical results reveal important influences on growth from government policies and public institutions.

Some researchers, such as Huntington (1996), Landes (1999), and Inglehart and Baker (2000), argue that explanations for economic growth should go further to include a nation's culture. Culture is usually thought to influence economic outcomes by affecting personal traits such as honesty, thrift, willingness to work hard, and openness to strangers. Religion is one important dimension of culture. Thus, Weber (1930) argued that religious practices and beliefs had important consequences for economic development. Nevertheless, economists and other researchers have paid little attention to religion and other measures of culture as determinants of economic growth. Our principal aim in this paper is to fill this gap by analyzing the influences of religious participation and beliefs on a country's rate of economic progress.

The most difficult inference problem in the social sciences involves the sorting out of directions of causation with non-experimental data. In our case, we want to know how religiosity affects aggregate economic performance, but we also have to worry about 
reverse effects from economic development to religion. This reverse channel has, in fact, been the focus of a substantial literature in the sociology of religion.

One prominent theory in this literature is the secularization hypothesis, whereby economic development causes individuals to become less religious, as measured by church attendance and religious beliefs. The beliefs may refer to heaven, hell, an afterlife, God, and so on, or may just refer to tendencies of people to characterize themselves as religious. The secularization hypothesis also encompasses the idea that economic development causes organized religion to play a lesser role in political decision-making and in social and legal processes more generally. ${ }^{1}$

Economic development does not have a single dimension, but rather involves regular patterns of change in a number of economic, social, and political variables. For example, development typically features not only rising per capita incomes but also higher levels of education, urbanization, and life expectancy, and lower levels of fertility. The combined effects from higher life expectancy and lower fertility imply a shift in the age structure toward the old and away from the young. The effect of economic development on religiosity likely depends on the specific aspect of development, for example, more education means something different from lower fertility. Our analysis of a broad panel of countries has enough variation in the data to distinguish among these effects.

\footnotetext{
${ }^{1}$ The secularization hypothesis appears in Weber (1930), but he credits the idea to John Wesley's writings in the late 1700s. For more recent discussions, see Wilson (1966), Berger (1967), Martin (1978), and Chaves (1994).
} 
The secularization hypothesis remains controversial, and an important competing theory focuses on "market" or "supply-side" forces. ${ }^{2}$ This approach downplays the role of economic development and other "demand factors" for religion and focuses instead on competition among religion providers. A greater diversity of religions available in a country or region is thought to promote greater competition, hence, a better quality religion product, and, hence, greater religious participation and beliefs.

More fundamentally, the extent of religious diversity and competition are thought to depend on how the government regulates the market for religion. For example, the existence of an established state church — as in Scandinavia—is viewed as one source of a low degree of religious pluralism and, therefore, of low participation in organized religion.

Chaves and Cann (1992) extended this argument by using empirical measures of the extent of state involvement and interference with church activities. Greater state regulation of religion - which Chaves and Cann measured by, among other things, whether the government appoints or approves church leaders - was argued to decrease the efficiency of religion providers and, therefore, to generate lower rates of church attendance. However, state religion also typically involves subsidies, such as payments to church employees, and the collection of taxes dedicated to church uses. Economic reasoning suggests that these subsidies would encourage formal religious activityhence, the overall impact of a subsidized state church on religious participation could be positive.

\footnotetext{
${ }^{2}$ This literature gets some of its inspiration from Adam Smith's views on the favorable role of competition in the religion market; see Smith (1791, Book V, Article III). Important contributions include Stark and Bainbridge (1987), Finke and Stark (1992), Iannaccone (1991), and Finke and Iannaccone (1993).
} 
The opposite of subsidy is suppression, and some governments have sought to suppress religion, either specific ones or in general. For example, Communist countries, such as the Soviet Union and China, tried hard to eradicate organized religion. This oppression would be predicted to lower church attendance and religious beliefs.

Our approach to the determinants of religiosity assumes that demand and supply forces combine to influence levels of religious participation and beliefs. However, our primary interest in the present paper is not to assess the secularization hypothesis or the market model of religious participation. Rather, we study the determinants-or, at least, the correlates — of religiosity mostly to facilitate our analysis of the effects of religion on economic growth. Specifically, our study of religiosity suggests plausible instrumental variables that can be used to pin down the direction of causation from religion to economic performance, rather than the reverse. These instrumental variables have important influences on religiosity without (arguably) being heavily influenced by economic growth. The estimation procedure then reveals how differences in religiositydriven by the variations in the instrumental variables - influence economic growth.

Two instrumental variables that we use in our study of economic growth are dummy variables for the existence of a state religion and the existence of a regulated market structure, whereby the government approves or appoints church leaders. In some of the analysis, we also use as instruments the composition of a country's population across the main religions among the population that adheres to some religion. We also use as an instrument a measure of religious diversity constructed from the data on religious adherence. 


\section{Data on Religiosity}

Our empirical research began with a previously constructed broad cross-country data set. The data include national-accounts variables and an array of other economic, political, and social indicators for over 100 countries observed since 1960. The main data sources are Heston, Summers, and Aten (2002), World Bank (2002), and Barro and Lee (2001).

We recently expanded this data set to include measures of religiosity. The most useful sources of international data on church attendance and religious beliefs seem to be the surveys reported in the three waves of the World Values Survey or WVS (1981-84, mostly 1981; 1990-93, mostly 1990; and 1995-97, mostly 1995 and 1996), the two reports on religion by the International Social Survey Programme or ISSP (1990-93, mostly 1991; and 1998-2000, mostly 1998), and the Gallup Millennium Survey (1999). Another wave of the WVS applies to 2000-01 and will soon be available.

At present, we are using the survey data only to form country-wide averages of data. This perspective accords with our emphasis in this paper on country-wide policies related to religion, including the presence of official state churches and regulation of the religion market. In subsequent analysis, we plan to use the individual data, which typically apply to $1000-2000$ respondents in each survey.

Putting the various sources of religion data together, and considering the availability of data on other variables, we are presently able to carry out statistical analysis for up to 59 countries, which includes up to 23 countries observed around 1981, 37 around 1990, 22 around 1991, 32 around 1995, 28 around 1998, and 41 around 1999. ${ }^{3}$

\footnotetext{
${ }^{3}$ For the 1981 data, the information from $W V S$ is combined with Gallup data on weekly church attendance and belief in God for Bulgaria, Poland, and Romania and with Gallup data on belief in life-after-death for
} 
The exact sample size depends on the measure of religiosity. The 2001 wave of the WVS will provide religion data for around 70 countries for which data on other variables are also available. Hence, the forthcoming release of this new wave will allow a substantial increase in the sample.

Table 1 shows the 59 countries in the sample. The coverage is better for rich countries than for poor ones and for countries that are primarily Christian. ${ }^{4}$ The predominantly Muslim countries are Bangladesh, Malaysia, Pakistan, and Turkey. ${ }^{5}$ Countries that have predominantly eastern religions (including Buddhist), among persons expressing some religious adherence, are China, Hong Kong, Japan, South Korea, Singapore, Taiwan, and Thailand. ${ }^{6}$ Malaysia also has substantial representation in these religions.

Some of the survey questions relate to attendance at religious services. We use these responses to generate the fractions of the population that attended church or analogous houses of worship at least weekly and at least monthly. Subsequently, we call this variable church attendance. Some of the surveys (the two ISSP waves) include

Brazil, India, Philippines, Singapore, and Thailand. For the 1990 data, the information from WVS is combined with data from Eurodim for Greece in 1987 on church attendance and belief in God. For the 1991 data, for some countries for which church attendance data were unavailable from the 1991 ISSP, we used information from the 1993 or 1994 ISSP (which has information on church attendance but not religious beliefs). These countries are Canada, Israel, Japan, Spain, Sweden, Bulgaria, Czech Republic, and Slovenia. For Israel and Slovenia, the 1991 ISSP has data on religious beliefs but not church attendance. The data for Israel from the 1991 and 1993 ISSP refer to the Jewish population only, whereas the 1998 data refer to the overall Israeli population. Our analysis takes account of these differences in religious composition. The data from $W V S$ and ISSP give separate information for Great Britain and Northern Ireland. In the present analysis, we combined these two sets of results into single observations for the United Kingdom, based on the relative populations of Great Britain and Northern Ireland.

${ }^{4}$ Included here are several countries that are predominantly Orthodox-Cyprus, Greece, Bulgaria, Romania, and Russia. Estonia and Latvia also have high Orthodox representations.

${ }^{5}$ Azerbaijan and Nigeria have religion data and are primarily Muslim. However, missing data on other variables prevented the inclusion of these countries in our sample. The 2001 wave of the $W V S$ will allow a substantial increase in observations on Muslim countries.

${ }^{6}$ Some of these countries, notably South Korea, have experienced large increases in Christian adherence over the last 30 years. The 2001 wave of the WVS will provide more observations on East Asian countries. 
questions about time spent at prayer. Other queries concern religious beliefs and attitudes; for example, do you believe in heaven, hell, life after death, and God (in various senses) $?^{7}$ Other questions, which might be more robust across religions, are whether the respondent considers himself or herself to be a religious person and whether religion plays an important role in a person's life.

We used tables from the first edition of the World Christian Encyclopedia (Barrett [1982]) to assemble information on religious adherence, as professed in surveys or censuses in which people are asked to state the religion, if any, to which they adhere. These, data which apply to 1970 and $1980,{ }^{8}$ allow us to construct measures of religious pluralism, based on Herfindahl indexes for the religion shares. ${ }^{9}$ Table 1 shows the values of the pluralism indexes that apply in 1980 to the countries used in the statistical analysis (as dictated by data availability). Countries with low levels of pluralism (values of the index close to zero) include some that are predominantly Catholic (Spain, Italy, Portugal, Belgium, Ireland, and much of Latin America), Protestant Scandinavia, Orthodox Greece,

\footnotetext{
${ }^{7}$ The meaning of some of these questions is unclear for some religions. For example, Hinduism and Buddhism view heaven and hell as intermediate stages between reincarnations, whereas Christianity regards heaven and hell as ends, not means, to salvation. See McCleary (2003) for further discussion. ${ }^{8}$ For some of the eastern European countries, which did not exist or were not covered in Barrett's (1982) first edition, the data come from Barrett, Kurian, and Johnson (2001) and refer to 1970 and 1990. An alternative procedure would be to use the country-wide averages of religion data in the various surveys. We did not proceed this way because the categories of religion differ across the surveys and because of some coding problems for religions in the World Values Survey.

${ }^{9}$ We grouped data on religious adherence from Barrett (1982) into nine major categories: Catholic, Muslim, Protestant, Hindu, Buddhist, other eastern religions, Jewish, Orthodox, and other religions. The Herfindahl index - the sum of the squares of the population fractions belonging to each religion - can be interpreted as the probability that two randomly selected persons in a country (among those adhering to some religion) belong to the same religion. Hence, our pluralism index - which we define to equal one minus the Herfindahl index - is the probability that they belong to different religions and can, therefore, be viewed as an indicator of religious pluralism or diversity. (Implicitly, the differences between the religious groupings are assumed to be the same for all pairs. Otherwise, one could weight religions in accordance with the extent of differences between them.) The Herfindahl index equals one and, hence, the pluralism indicator equals zero if everyone belongs to the same religion. If there are two religions of equal size, the Herfindahl and pluralism variables each equal one-half. The Herfindahl index equals (almost) zero and, hence, the pluralism indicator equals (almost) one if there are a large number of religions each of which covers a negligible fraction of the population. With nine groupings, the lowest possible value of the Herfindahl index is 0.11 , so that the highest possible value of the pluralism measure is 0.89 .
} 
and Muslim Pakistan and Turkey. Places that exhibit high levels of pluralism (values of the index of 0.5 or higher) include the United States, Germany, the Netherlands, Switzerland, Australia, Malaysia, Singapore, and South Africa.

We used Barrett, Kurian, and Johnson's (2001, pp. 834-35) tabulations to measure the presence or absence of a state religion. These classifications are clearer in some cases than in others. In some of the straightforward situations, the constitution designates an official state church and restricts or prohibits other forms of religion. However, even without these designations or prohibitions, the government may systematically favor a religion through subsidies and tax collections or through the teaching of religion in public schools. These considerations caused Barrett, et al, to classify some countries as having a "state religion," despite the absence of an official state church in the constitution. Controversial cases in this category include Italy, Portugal, and Spain, which are considered by Barrett, et al, to have a Catholic state religion even in 2000. Table 1 shows the classifications in 1970 for the countries used in the analysis.

We used Barrett's (1982) and Barrett, Kurian and Johnson's (2001) discussion of each country (supplemented in some cases by individual country reports) to obtain a proxy for state regulation of religion. We used the concept suggested by Chaves and Cann (1992) — whether the government appoints or approves church leaders. The Barrett, et al, discussions of this concept typically refer to the late 1970s. However, the information is often incomplete and is not fully consistent across countries. The data used in the present analysis are in Table 1.

In subsequent research, we plan to use the Religion and State $(R A S)$ data set, which is described in Fox and Sandler (2003), to improve on our measures of state 
religion and state regulation of religion. We will also be able to add measures of state subsidy and suppression of religion. The $R A S$ tabulation measures the relation between religion and state in numerous categories, broken down among the separation of religion and state, discrimination against minority religions, restrictions on majority religions, and religious legislation. These data will eventually be available for most countries back to 1960. However, at present, the tabulation is complete only for a subset of countries and only starting in 1990.

\section{Cross-Country Findings on Religiosity}

As a prelude to our analysis of the effects of religion on economic growth, we estimated panel systems in which the dependent variables are country averages of answers to survey questions about attendance at religious services and religious beliefs. The explanatory variables include a set of country-wide factors: economic and demographic variables, government policies and institutions related to religion, the country's composition of adherence to the major religions, and the measure of religious pluralism, which is constructed from the data on adherence.

The product from this exercise is a set of partial correlations at the country-wide

level between the measures of religiosity and the explanatory variables. For example, we determine how church attendance and beliefs co-vary with per capita GDP, education, and urbanization, while holding fixed other measures of economic development and the other independent variables. These partial associations provide useful information, but they may not have simple causal interpretations. For example, if the partial relation between church attendance and education is positive (as turns out to be true), it does not 
necessarily follow that an increase in average education generates more church

attendance. For one thing, we have to worry about reverse causation, for example, the possibility that the estimated relation reflects the reverse impact of church attendance on education. Moreover, even if the estimated effect of schooling on church attendance were causal, it would not necessarily mean that an increase in an individual's schooling would cause that person to attend church more frequently. Conceivably, church attendance could rise with education at the level of society but fall with education at the level of individuals within a society. To distinguish country-wide effects from individual effects, we would have to use micro data, as well as deal with the issues of causality. ${ }^{10}$ However, these concerns do not prevent our using the analysis of religiosity for our prime purpose, which is to isolate instrumental variables for our study of economic growth.

\section{A. Setup of the Panel Estimation}

Table 2 contains panel estimates for systems in which the dependent variables are measures of religiosity. Table 3 shows the means and standard deviations of the variables used in the analysis. In column 1 of Table 2, the dependent variable is based on the fraction of the population who attend religious services (at churches or analogous houses of worship) at least monthly. ${ }^{11}$ Column 2 is based on the fraction who believe in heaven and column 3 on the fraction who believe in hell. ${ }^{12}$ Results for the fraction of persons who believe in an after-life turn out to be basically similar. We have also considered the

\footnotetext{
${ }^{10} \mathrm{We}$ are considering the micro evidence in ongoing research. However, the micro analysis brings in other problems, particularly with respect to the accuracy of data on income, education, health, and urbanization.

${ }^{11}$ We get similar results for the fraction of the population who attend church at least weekly. For the WVS and Gallup Millennium Survey, the attendance variables come from answers to the question "Apart from weddings, funerals and christenings, about how often do you attend religious services these days?" For the $I S S P$ data, the question is "How often do you attend religious services?"

${ }^{12}$ For WVS and ISSP, the questions are "Do you believe in Heaven?" and "Do you believe in Hell?" These questions are not in the Gallup Millennium Survey.
} 
fraction of the population who believe in God (in some sense), as well as the fraction of persons who consider themselves religious or for whom religion plays an important role. However, these other measures turned out to be less useful in our subsequent analysis of economic growth. The form of each dependent variable in Table 2 is the transformation $\log [\mathrm{x} /(1-\mathrm{x})]$ of the original series $\mathrm{x}$. This form confines the fitted value of $\mathrm{x}$ to the interval $(0,1) .^{13}$

Each system in Table 2 comprises five or six equations corresponding to the religiosity survey data. The first equation is for data around 1981 from the World Values Survey (WVS), the second is for data around 1990 from $W V S$, the third is for data around 1991 from the International Social Survey Programme (ISSP), the fourth is for data around 1995 from $W V S$, the fifth is for data around 1998 from ISSP, and the last is for 1999 data from Gallup (which lacks data for belief in heaven and hell).

Our panel estimation technique allows us to combine countries that are represented in different surveys, as well as to include multiple observations for a single country. We recognize, however, that observations at different points in time or from different survey sources for a single country would not be independent. Therefore, we use the method of seemingly unrelated regression (SUR), which estimates (along with the coefficients) the correlations of the error terms in the equations for the different surveys for a given country. We also allow for differences in average survey results across the

\footnotetext{
${ }^{13}$ In this form, the marginal effect of an independent variable on $\mathrm{x}$ equals the coefficient of the variable multiplied by the quantity $\mathrm{x} \cdot(1-\mathrm{x})$. Hence, the marginal effect of an explanatory variable on $\mathrm{x}$ diminishes in magnitude as $x$ approaches zero or one. For a broad range of $x$ - say between 0.2 and 0.8 - the functional form is roughly linear.
} 
sources by including a different intercept term for each source-WVS, ISSP, and Gallup. $^{14}$

The explanatory variables include four measures of economic development: real per capita gross domestic product (GDP), average years of school attainment of the adult population aged 25 and over, the urbanization rate (typically the fraction of the population living in places with at least 2500 people), and life expectancy. This last variable appears as the reciprocal of life expectancy at age one and, hence, corresponds roughly to the average mortality rate per year. The systems also include two measures of age structure: the fractions of the population aged over 65 and under $15 .^{15}$ These variables are also related to economic development, in that richer countries tend to have relatively large elderly populations and relatively small child populations.

Previous analyses of the determinants of religiosity have tended to look at economic development as a single dimension. However, the present cross-country panel includes enough observations to allow separation of effects from the individual dimensions of development. The breadth of the data is crucial when trying to disentangle, for example, the relationships with education, urbanization, per capita GDP, and life expectancy, all of which typically rise along with economic development. ${ }^{16}$

Another set of explanatory variables included in Table 2 measures the composition of the population by major religion in 1980. The present analysis uses an

\footnotetext{
${ }^{14}$ Formally, we included a constant term and two dummy variables, one for the ISSP source and one for the Gallup source. The Gallup dummy was excluded in the systems for belief in heaven or hell, for which Gallup data were unavailable.

${ }^{15}$ The GDP data are from version 6.1 of the Penn World Tables, which are described in Summers and Heston (1991) and Heston, Summers, and Aten (2002). These values, available on the Internet, adjust for purchasing power differences across countries. Most of the other data are from World Bank (2002). The schooling data are described in Barro and Lee (2001).

${ }^{16}$ Inglehart and Baker (2000) use a single cross-section from the World Values Survey to assess the relation of religious and other values to per capita GDP and industrial structure. They also look at effects from different religions and from a history of Communist government.
} 
eight-way breakdown: Catholic, eastern religions (including Buddhist), Hindu, Jewish, Muslim, Orthodox, Protestant, and other religions. ${ }^{17}$ In each case, the variable refers to the fraction adhering to the specified religion among persons who expressed adherence to some religion. ${ }^{18}$ The specification omits the Catholic fraction as a normalization. Hence, each coefficient should be interpreted as the effect from the indicated religion relative to that for Catholic.

The regression systems also include the previously mentioned pluralism measure, which is computed from the Herfindahl index for the various religion shares in 1980 (1990 for some eastern European countries). This index was calculated from a nine-way breakdown of religious adherence that distinguishes Buddhist from other eastern religions. We discuss later some criticisms that have been raised about this type of measure of religious pluralism.

Finally, the system includes a number of variables related to government influences on the religion market. These variables are the dummy for the presence of an official state religion, the dummy for whether the government regulates the religion market (by appointing or approving church leaders), and dummies for the presence and subsequent removal of Communist regimes. ${ }^{19}$

\footnotetext{
${ }^{17}$ Buddhist and other eastern religions were combined because of a lack of sufficient data from Asian countries to distinguish these two categories. Our present data do not allow us to break down religions into denominations, for example, among types of Muslims and Protestants.

${ }^{18}$ The composition of religious adherence across persons who exhibit some adherence may conceivably be exogenous with respect to church attendance and religious beliefs. However, it is unreasonable to regard the breakdown between some and no adherence (appearing in the data as non-religious or atheist) as exogenous with respect to attending church or holding religious beliefs. Therefore, it would be inappropriate to include among the explanatory variables a measure of the fraction of the population that expressed no religious adherence.

${ }^{19}$ The countries included in the sample that are designated as Communist up to 1990 are Russia, China, several Eastern European countries, and the Baltic republics (see Table 1). All of these countries except China are designated as ex-Communist after 1990. Several former Soviet republics and several parts of the former Yugoslavia that are covered by the World Values Survey are excluded from the sample because of missing data on other variables - these are Armenia, Azerbaijan, Belarus, Bosnia, Croatia, Georgia,
} 


\section{B. Relations with Economic Variables}

The data reveal an overall pattern in which economic development is associated with less religiosity, measured by church attendance or religious beliefs. This pattern can be seen in simple relations between a measure of religiosity and per capita GDP, which we take as the basic indicator of economic development. As examples, negative associations with the log of per capita GDP appear for monthly church attendance in Figure 1, for belief in heaven in Figure 2, and for belief in hell in Figure 3. The simple correlations with the log of per capita GDP are -0.51 for the monthly-church-attendance variable, -0.48 for the belief-in-heaven variable, and -0.51 for the belief-in-hell variable. ${ }^{20}$

The statistical results in Table 2 reveal very different patterns for the individual dimensions of economic development. These results reflect partial relationships. For example, the regression framework isolates a significantly positive relation between education and church attendance, while holding constant the other development indicators - per capita GDP, urbanization, life expectancy, and age structure - and the other explanatory variables shown in Table 2 . The estimated coefficient of 0.19 (s.e. $=0.04)$ in column 1 implies that 2.1 extra years of average schooling (the sample standard deviation of this variable, as shown in Table 3) is associated with 10 percentage points more of monthly attendance, starting from the mean value for attendance of $36 \%$. Table 2 shows that positive, partial relations with education appear also for beliefs in heaven and hell.

Macedonia, Moldova, Montenegro, Serbia, and Ukraine. East Germany is also excluded because of missing data.

${ }^{20}$ The data plotted in the figures and the correlations are for all the available country-time observations. The numbers of observations are 186 for monthly attendance and 133 for each of the beliefs. 
Another clear pattern in Table 2 is the significantly negative relation between the measures of religiosity and the urbanization rate. The estimated coefficient of -1.5 (s.e. $=0.3$ ) for monthly church attendance in column 1 means that an increase in the urbanization rate by 0.15 (its sample standard deviation) is associated with lower monthly attendance by about 5 percentage points. Similar patterns apply to the beliefs in heaven and hell.

Table 2 shows marginally significant negative relations between church attendance and life expectancy. The estimated coefficient of $2.2($ s.e. $=1.2)$ in column 1 means that a fall in the reciprocal of life expectancy by 0.08 (its sample standard deviation) is associated with lower monthly church attendance by about 4 percentage points. In contrast, the results show marginally significant positive relations between life expectancy and the beliefs in heaven and hell.

The estimates shown in Table 2 indicate that, once the other development indicators are held constant, the relation between monthly church attendance and per capita GDP is close to zero. The relation of the religious beliefs to per capita GDP is negative but not statistically significantly different from zero.

For age structure, one result in Table 2 is that a greater presence of children (higher population share under age 15) goes along with significantly higher monthly church attendance. The relation between the presence of children and the religious beliefs tends also to be positive, though these relations are not statistically significantly different from zero. The old-age fraction is not significantly related to monthly church attendance but is negatively and significantly related to the religious beliefs. 
Although we have mentioned the potential pitfalls in making causal inferences, we can note how the observed patterns of partial correlation in the aggregate data relate to theories of the effects of economic development on religiosity. The positive association between education and church attendance accords with Sacerdote and Glaeser's (2001) argument that more educated people have a greater incentive to participate in group activities, including church services. The positive relation between education and the religious beliefs is more surprising and, in fact, conflicts with Sacerdote and Glaeser's (2001) findings on micro data within countries.

The results on life expectancy and the elderly fraction of the population relate to Azzi and Ehrenberg's (1975) theoretical argument that a concern about salvation would motivate people to participate more in religious activities as they age and, hence, get closer to death. This theory may explain the negative association between life expectancy and monthly church attendance but not the positive association between life expectancy and religious beliefs. The weak results for the old-age fraction may arise because the increased incentive to attend religious services is offset by high costs of attendance due to ill health and immobility.

The positive association between the young-age fraction and monthly church attendance may reflect the relatively low cost of participation for children. Another consideration is that time spent at formal services is likely to be especially productive in terms of belief formation at young ages. Moreover, the parents of young children typically accompany their children at religious services.

Finally, the inverse association between urbanization and church attendance is consistent with the view that church services have to compete in urban areas with many 
other leisure activities, such as museums, theatres, and political organizations. A possible

explanation for this urban/rural pattern is that economies of scale are important for many social organizations but are less significant for houses of worship. Even sparsely

populated rural towns can sustain a local congregation.

\section{State Religion, State Regulation, and Communism}

Table 2 shows that the estimated coefficients on the state-religion dummy variable are significantly positive for monthly church attendance. The estimated coefficient of 0.87 (s.e. $=0.14$ ) in column 1 implies, if viewed causally, ${ }^{21}$ that the imposition of a state religion would raise the monthly church attendance rate by 21 percentage points (starting from the mean of 36\%). ${ }^{22}$ This pattern conflicts with the one predicted in the religion-market model of Stark and Bainbridge (1987), Iannaccone (1991), Finke and Stark (1992), and Finke and Iannaccone (1993). In that view, state

\footnotetext{
${ }^{21}$ One potential concern is that greater religiousness among the population might help to explain why a country has a state religion. One opposing argument is that many of the state religions, such as Lutheranism in the Scandinavian countries, were implemented many decades ago. Moreover, the introduction of a state religion often accompanied a change in the political regime, which we can reasonably regard as exogenous with respect to religiosity. However, it could be argued that less religious nations would be more likely to abandon their state religions. Thus, Sweden removed Lutheranism as the state religion in 2000-however, it took more than 400 years from the date of establishment.

${ }^{22}$ These results apply when we use the status of state religion as of 1970. Our sample does not contain enough instances of change after 1970 to assess the dynamic responses of church attendance and religious beliefs. The main example of a shift since 1970 is Ireland's abandoning Catholicism as its state religion in 1972, although Barrett, Kurian, and Johnson (2001) continue to classify Ireland as officially religious but not officially Catholic. Legislative changes also occurred after 1970 in Italy, Portugal, and Spain, but Barrett, et al, continue to label these countries as maintaining Catholic state religions even in 2000. In 1991, the Bulgarian constitution recognized the Eastern Orthodox church as the country's traditional religion. More recently, Sweden dropped the Lutheran church as its state religion. If we compare 1970 with 1900, we find many examples of countries abandoning state religions. Using Barrett, Kurian, and Johnson's (2001) data, examples for countries in our sample are Brazil, Chile, China, Japan, South Korea, Turkey, Latvia, Lithuania, Romania, and Russia. Some countries that were not independent in 1900 (Bangladesh, Israel, and Pakistan in our sample) introduced state religions when they became independent. We also have information from Barrett, Kurian, and Johnson (2001) for governments that are officially religious, although not maintaining a single religion. Examples in 1970 for countries in our sample are South Africa, Brazil, Philippines, Belgium, Cyprus, Germany, Switzerland, and Australia. If we enter an additional dummy variable into the systems of Table 2 to capture this officially religious category, the estimated coefficients on this new variable are close to zero.
} 
religion promotes monopoly and, therefore, poor service and low rates of church attendance. However, since state religion typically goes along with state subsidy, it is not surprising that the overall relation between state religion and church attendance would be positive.

The results for state religion apply when we hold constant the measure of religious pluralism (discussed below). One part of the argument in the religion-market model is that an established state religion will sustain a low diversity of religion. Hence, the pluralism variable could be getting credit for some of the influence on church attendance that stems ultimately from the presence of an established religion. If we delete the pluralism index from the system for monthly church attendance, the estimated coefficient on the state religion dummy becomes 0.57 (s.e. $=0.14$ ), which is smaller than before but still significantly positive. Our analysis also includes the dummy variable for the presence of state regulation of religion. Since this regulatory system often accompanies a state religion (see Table 1), the regulatory variable could be getting credit for effects that stem ultimately from state religion. If we delete the regulatory variable, as well as the pluralism index, from the system for monthly church attendance, the estimated coefficient on the state religion dummy falls further to $0.29(0.14)$.

In the literature, the Scandinavian countries are often cited as places in which state churches co-exist with low rates of church attendance. That pattern does characterize the data in our study. However, the low rates of attendance in these countries turn out to be well explained by the model estimated in Table 2, despite the positive coefficient on the state-religion dummy. For example, in the system for monthly church attendance (column 1), the residual for Sweden in 1990 is actually positive. That 
is, although monthly church attendance is only $10 \%$, it exceeds the value predicted by the model. The reason is that the other variables contained in the system - notably the overall influence of the economic variables and the composition of religions (discussed in the next section) - predict low rates of church attendance. This pattern applies also to the other Scandinavian countries-Denmark, Finland, Iceland, and Norway—all of which have state religions.

Table 2 shows that the estimated coefficients for the state-religion dummy are also significantly positive for beliefs in heaven and hell. For example, the estimated coefficient for belief in heaven in column 2 is 1.07 (s.e. $=0.18$ ). This result, if viewed causally, indicates that the state sponsorship that encourages church attendance is also somewhat successful in engendering high levels of beliefs. ${ }^{23}$

As before, the effects from state religion may interact with the influences of religious pluralism and government regulation. If we delete the pluralism variable from the system for belief in heaven, the estimated coefficient on the state religion dummy falls to 0.77 (s.e. $=0.16$ ). If we also delete the dummy variable for state regulation of religion, the estimated value falls further to 0.62 (0.15). Although this estimated coefficient is about half that found in column 2 of Table 2 , it is still significantly positive. $^{24}$

The results in Table 2 suggest that government regulation of religion depresses church attendance and belief in heaven. That is, the argument from the religion-market model about the negative effects of government involvement on religious participation

\footnotetext{
${ }^{23}$ Again, the reverse interpretation would be that strong religious beliefs make it more likely that a state religion exists.

${ }^{24}$ For belief in hell, the estimated coefficient on the state religion dummy in column 3 of Table 2 is 0.79 (s.e. $=0.17)$. With the pluralism measure deleted, the estimated coefficient becomes $0.53(0.15)$. With the regulation variable also deleted, the estimated coefficient is $0.49(0.14)$.
} 
are consistent with the negative coefficients estimated for public regulation. Better measurement of the indicator for regulation may sharpen these results.

Quantitatively, the estimated coefficient of -0.64 (s.e. $=0.11)$ on the state regulation dummy variable in column 1 of Table 2 means, if viewed causally, that the introduction of a government regulatory system for religion would lower monthly attendance by 13 percentage points. As already noted, state religion and government regulation of religion often come as a package — see Table 1 . If a state religion is imposed along with regulation, the estimated net effect on monthly church attendance is positive but by only about 5 percentage points.

The presence of a Communist regime has a substantial negative relation with church attendance and religious beliefs. Specifically, the estimated coefficient of -0.70 (s.e. $=0.20)$ in column 1 of Table 2 implies that the presence of a Communist regime is associated with lower monthly church attendance by 14 percentage points.

By comparing the three later surveys_-WVS around 1995, ISSP around 1998, and Gallup in 1999 — with the three earlier ones, we can estimate how the downfall of Communist regimes in the early 1990s affected religiosity. The results are that church attendance and religious beliefs tended to recover in the former Communist countries during the $1990 \mathrm{~s}^{25}$ For example, in the 1999 equation for monthly church attendance, the estimated net remaining effect from the presence of Communism before 1990 is given

\footnotetext{
${ }^{25}$ Poland is an exception, as it exhibits a small decline in church attendance during the 1990s. However, Poland is even more of an outlier with respect to its high rates of church attendance in earlier years. For example, the estimated model (Table 2, column 1) explains little of the high rate of monthly church attendance in 1990. The popularity of organized religion during the Communist period has been attributed to the Catholic church's position as chief political opponent of the government. The decline in religious participation in the 1990s could then reflect the elimination of this political role for the church, once the Communist regime collapsed. Although these arguments seem reasonable, they have the shortcoming of explaining the vibrancy of religion in Poland up to 1990 by observing that it was vibrant. The question is, why did religion occupy a different place in Poland from, say, in Hungary or Czechoslovakia, which were also historically predominantly Catholic?
} 
by the coefficient on the Communism dummy, -0.70 , plus the coefficient for ex-

Communism (in 1999), 0.59. Hence, the net remaining effect for 1999 is a coefficient of -0.11 , implying a net reduction of monthly attendance by only $2-1 / 2$ percentage points. ${ }^{26}$

\section{Religious Pluralism and the Composition of Religions}

Table 2, column 1 shows that the religious pluralism indicator (shown in Table 1) has a significantly positive coefficient in the system for monthly church attendance. This pattern accords with the religion-market model's argument that greater diversity of religion would encourage competition among religion providers and lead, thereby, to better service and higher rates of attendance. The estimated coefficient of 1.35 $(\mathrm{s} . \mathrm{e} .=0.32)$ means that an increase in pluralism by 0.23 (its sample standard deviation) is associated with higher monthly church attendance by about 7 percentage points.

Religious pluralism also has significantly positive coefficients in the systems for belief in heaven and hell (columns 2 and 3 of Table 2).

Chaves and Gorski (2001) and Voas, Olson, and Crockett (2002) have criticized the use of this kind of measure of religious pluralism. These authors point out problems that arise particularly when the pluralism measure is constructed as a transformation of the same data that are used to form the dependent variable. For example, in some studies, pluralism was calculated from the fractions of the population affiliated with the various religions (Catholic, Protestant, etc.), and the dependent variable was computed as the fraction of the population affiliated with any of the religions. We agree that this procedure is problematic because it creates a mechanical relation between the dependent

\footnotetext{
${ }^{26}$ Another example of the religious recovery is that the 1991 Bulgarian constitution specified the Eastern Orthodox church as the traditional religion of Bulgaria.
} 
and independent variables, that is, a relation that does not involve a causal link between religious diversity and religiosity. However, our situation is different, because the independent variable is calculated from the fractions of the adhering population affiliated with the various religions, whereas the dependent variable is the fraction of the total population who attend church (or believe in heaven, etc.). In this case, no mechanical relation exists between the dependent and independent variable.

Another way to look at our specification is that it includes linear terms in religion shares (fractions of the adhering population who are Protestant, Muslim, etc.), as well as a variable - the pluralism indicator — that is constructed from the squared values of the religion shares. Thus, the issue for us is not, per se, whether the pluralism indicator is a satisfactory independent variable but rather whether the religion shares are appropriate. In this context, the key matter is whether the religion shares are endogenous, that is, whether shifts in religiosity (church attendance and beliefs) affect these shares. As in our discussion of the economic variables, endogeneity of the right-hand side variables would make it difficult to attach causal inferences to the estimates.

Consider now the estimated coefficients on the religion shares. Recall that the Catholic share was omitted as a normalization, so that the coefficients reveal the relations relative to that for Catholic. Recall also that the share variables are the fractions of the population adhering to the indicated religion among persons who express adherence to some religion.

Table 2, column 1 shows that most of the coefficients on the religion shares are negative. Hence, for given values of the other explanatory variables, most religions are 
lower than Catholic in terms of monthly church attendance. ${ }^{27}$ The exceptions are Muslim and other religions, which have coefficients that differ insignificantly from zero. For the religious beliefs, shown in columns 2 and 3, most of the religions are again lower than Catholic. However, Muslim and other religions are positive. Particularly striking are the large positive coefficients for the Muslim religion in the system for belief in heaven and, even more so, for belief in hell.

\section{Determinants of Economic Growth}

We now consider religion's role in the determination of economic growth. Our central perspective is that religion affects economic outcomes mainly by fostering religious beliefs that influence individual traits such as thrift, work ethic, honesty, and openness to strangers. For example, beliefs in heaven and hell might affect these traits by creating perceived rewards and punishments that relate to "good" and "bad" lifetime behavior. In this perspective, organized religion — and, more specifically, attendance at religious services—-would affect economic performance mostly indirectly, that is, through influences on the religious beliefs. Hence, we envision a chain whereby church attendance affects religious beliefs, which affect individual traits, which affect economic outcomes.

To put in another way, we view religious beliefs as the principal output of the religion sector, ${ }^{28}$ and we view church attendance as one of the inputs to this sector. Thus, if we hold fixed the beliefs — as we do in the regressions that we highlight—an increase

\footnotetext{
${ }^{27}$ These results can reflect differences across religions in the role of attending church or analogous houses of worship. For example, religions vary by the weights they attach to organized services and to professional clergy versus personal prayer.

${ }^{28}$ The religion sector does have outputs aside from the promotion of religious beliefs. For example, organized religion can be important in social-welfare activities and education.
} 
in church attendance signifies that the religion sector is less productive. That is, more resources, in terms of time and goods, are being consumed for given outputs (beliefs). Hence, our anticipation is that, for given religious beliefs, higher church attendance would show up as a negative influence on economic performance.

A different perspective, represented by Sacerdote and Glaeser (2001) and Putnam (2000), argues that houses of worship are important as civic organizations, per se. That is, the networks and interactions fostered by churches are important as elements of social capital. In this case, we might find that, for given religious beliefs, church attendance would have a separate, positive effect on economic performance. Church attendance would also gauge the importance of organized religion in society, and organized religion may have economic effects that go beyond the consumption of resources (negative for growth) or promotion of beliefs (which we hold constant). For example, organized religion might influence laws and regulations that affect economic incentives. Adverse examples would be restrictions on credit and insurance markets and more general discouragement of the profit motive. These channels provide additional reasons why church attendance might show up as a negative influence on economic growth, when we hold fixed religious beliefs.

Our empirical framework for studying economic growth is the one described in Barro (2000) and Barro and Sala-i-Martin (2003, Ch. 12). The dependent variable is the growth rate of per capita GDP over the periods 1965-75, 1975-85, and 1985-95. The explanatory variables, suggested by previous studies, are the values at the start of each period of the log of per capita GDP, life expectancy, years of school attainment, and the total fertility rate; average ratios of investment and government consumption to GDP; an 
openness measure based on the ratio of exports plus imports to GDP; changes in the terms of trade; subjective measures of maintenance of the rule of law and democracy; and the inflation rate. In the present analysis, we add measures of religiosity to this list of explanatory variables.

The regressions include all countries that have data on all of the variables. We began with a sample of 87 countries, but the inclusion of data on church attendance and religious beliefs lowered the sample to 41 countries. We end up with 2 countries in subSaharan Africa, 8 in Latin America, 9 in Asia, 2 in Eastern Europe, and 20 that have been members of the OECD since the 1960s (not including Japan and Turkey, which are included with Asia).

Our empirical results are in Table 4. Each system includes as explanatory variables a measure of monthly church attendance and a measure of religious belief-in the present case, belief in heaven or hell. (These variables enter, as before, in the form $\log [\mathrm{x} /(1-\mathrm{x})]$, where $\mathrm{x}$ is the fraction of persons attending or believing.) In order to minimize the loss of observations, we entered into the regressions a single measure of monthly church attendance or religious belief for each period for countries that had data on these concepts at any point in time. Specifically, we defined a measure of attendance or belief for a country to be the value from WVS 1990 if available, then we filled in with the value from WVS 1981 if the 1990 value was unavailable. (We adjusted for the average discrepancy between the two values among countries that had information for both years.) If neither of these values were available, we used in an analogous way the value for ISSP 1991, then WVS 1995, then ISSP 1998, and finally Gallup 1999. This 
procedure means that the systems for economic growth incorporate on the right-hand side measures of religious attendance and beliefs that sometimes post-date the growth rates.

One reason that the use of later observations on the right-hand side of the growth equations may be satisfactory is that church attendance and religious beliefs exhibit a lot of persistence over time. Hence, later values may proxy satisfactorily for the missing earlier ones, which can be viewed as the true causes of differences in growth rates. However, the results summarized in Table 2 suggest substantial responses of religiosity to economic variables. Thus, there is a good chance that the religion measures would pick up reverse causation from economic development to religiosity, rather than the reverse.

To deal with the reverse-causation issue, we use instrumental variables suggested by the regressions in Table 2, in which the religion measures were the dependent variables. Specifically, we use as instruments the dummy variable for the presence of a state religion (in 1970), the dummy variable for the existence of state regulation of religion (in the 1970s), and the pluralism index constructed from religion shares in 1970 or 1980 (among persons adhering to some religion). These three variables are highly statistically significant for explaining monthly church attendance, belief in heaven, and belief in hell—in each case, the p-value for joint significance is 0.000 . Thus, we do not have to be concerned that the instruments are weak.

In some cases, we also use as instruments the composition of religious adherence in 1970 or 1980. The compositional breakdown, corresponding to the one used in Table 2, is for eastern religions (including Buddhist), Hindu, Jewish, Muslim, Orthodox, Protestant, and other religions. As before, the shares are calculated relative to the total 
population of adherents to some religion, and the Catholic fraction is omitted as a normalization. The seven religion shares, together with the three variables mentioned before, are jointly highly statistically significant for explaining the religiosity variablesthe p-values for joint significance are again 0.000 .

It is possible that the proposed instruments-although prior in time to the growth observations - are themselves endogenous with respect to economic development. For example, over long periods, development could induce countries to drop their official state religions or to alter their regulatory systems for religion. For the composition of religions, the major concern is that these shares would matter directly for economic growth, not just through their predictive content for the religiosity measures. ${ }^{29}$ To check out these possibilities, the subsequent analysis includes tests of over-identifying restrictions of the model.

Columns 1 and 2 of Table 4 use the variable based on belief in hell. The first column excludes the religion shares in the growth equations. The main result, which typifies our findings, is that the estimated coefficient on monthly church attendance is negative, whereas that on religious belief - in this case, in hell—is positive. These estimated coefficients are individually and jointly statistically significant (p-value for the two together is 0.000 ). The estimated coefficient on the monthly attendance variable, -0.0095 (s.e. $=0.0018)$, means that an increase in this variable by one standard deviation $(1.20$, as shown in Table 3$)$ would reduce the growth rate on impact by 1.1 percent per year. The estimated coefficient on the belief-in-hell variable, $0.0094(0.0025)$, means

\footnotetext{
${ }^{29}$ It is also possible that economic growth would, over long periods, influence the composition of religious adherence. This process could involve religious conversion, differences in fertility across religions (combined with a relation between economic development and fertility patterns), and immigration (to the extent that development interacted with the pattern of migration by religious affiliation).
} 
that a rise in this variable by one standard deviation (1.06) would raise the growth rate on impact by 1.0 percent per year. ${ }^{30}$ Similar numerical calculations can be applied to the other results in Table 4 (using the standard deviations of variables shown in Table 3).

One test of over-identification is whether the first group of three instruments - the religious pluralism index and the dummies for the presence of a state religion and for regulation of the religion market—matter directly for growth. To carry out this test, we maintained the hypothesis that the religion shares do not enter directly into the growth equations. (This assumption allows us to identify the systems even when the group of three instruments is added to the growth equations.) The p-value for joint significance of the three variables in the growth equations is 0.25 . Similar results apply to the other cases shown in Table 4-we always accept with a high p-value the exclusion of the three variables from the growth equations. Therefore, for the rest of the analysis, we include these three variables — the pluralism index and the dummy variables for state religion and regulation of religion - as instruments but exclude them from the growth equations.

If we include the religion shares directly in the growth equations, we get the estimated coefficients shown in column 2 of Table 4. The coefficients on each religion share should be interpreted as the effect relative to that for Catholic. The estimated coefficients that are individually statistically significant are the negative values shown for Hindu, Muslim, Orthodox, and Protestant. Some of these signs are surprising, but a full interpretation has to consider that monthly church attendance and belief in hell are held constant, and these two variables are strongly related to religious composition (as shown

\footnotetext{
${ }^{30}$ If we include the monthly-church-attendance and belief-in-hell variables in the instrument lists (and exclude the other instruments associated with religion), we get the coefficient estimates $-0.0078(0.0017)$ on the attendance variable and $0.0088(0.0021)$ on the belief variable. These point estimates are smaller in magnitude than the ones we got with our instrumental variables.
} 
in Table 2). ${ }^{31}$ The religion shares are jointly statistically significant with a p-value of 0.001 .

Given that some of the religion shares matter directly for economic growth, we should also examine the estimated growth effects of church attendance and belief in hell when the religion shares are included in the growth equations. The resulting coefficients, shown in column 2 of Table 4 , are $-0.0156($ s.e. $=0.0044)$ for monthly church attendance and $0.0140(0.0058)$ for belief in hell. The p-value for joint significance is 0.001 . Therefore, the results from church attendance and belief in hell remain statistically significant even when the religion shares are included directly into the growth equations. Moreover, the quantitative effects implied by the point estimates become even larger than before.

Columns 3 and 4 of Table 4 replace belief in hell by belief in heaven. The results are similar to those found before, except that the quantitative effect and statistical significance for belief in heaven are somewhat less than those for belief in hell. For example, when the religion shares are excluded from the growth system in column 3 , the estimated coefficient on the monthly-church-attendance variable is $-0.0104(0.0023)$, whereas that on the belief-in-heaven variable is $0.0069(0.0029)$. The p-value for joint significance is 0.000 . When the religion shares are included in column 4 , the estimated coefficients are $-0.0123(0.0043)$ on the monthly attendance variable and $0.0076(0.0048)$

\footnotetext{
${ }^{31}$ As an example, if we do not include religiosity variables in the growth regressions, the estimated coefficient on the Muslim fraction is close to zero. The Muslim fraction is also associated with high belief in hell relative to church attendance (Table 2, columns 1 and 3), and this mechanism tends to encourage growth, according to the estimates in columns 1 and 2 of Table 4 . The results in column 2 suggest that, once the connections with belief in hell and church attendance are held constant, the remaining effect of Muslim adherence on economic growth is negative.
} 
on belief in heaven. In this case, the p-value for joint significance is 0.009 . Thus, the results are again robust to the inclusion of religion shares in the growth system.

We also looked at other measures of religious belief. A pattern of results similar to those shown in Table 4 emerges if we use a measure of belief in an after-life, rather than the more specific beliefs in hell or heaven. ${ }^{32}$ For example, in a specification comparable to those in columns 1 and 3 of the table, the estimated coefficients are $-0.0094(0.0021)$ on the variable for monthly church attendance and $0.0079(0.0035)$ on the variable for belief in an after-life. ${ }^{33}$

The results are much weaker if we use a measure of belief in God, rather than the more concrete beliefs in hell, heaven, or an after-life. In a specification comparable to those in columns 1 and 3 of Table 4, the estimated coefficients are $-0.0092(0.0030)$ on the monthly attendance variable and $0.0018(0.0030)$ on the belief-in-God variable. ${ }^{34}$ Thus, given church attendance, variations in professed belief in God have no explanatory power for economic growth. One possible reason is that most people in most countries reflexively answer yes to the question of whether they believe in God in some sense- - the

\footnotetext{
${ }^{32}$ We again used the functional form $\log [\mathrm{x} /(1-\mathrm{x})]$, where $\mathrm{x}$ is now the fraction of persons who expressed a belief in an after-life. For the $W V S$ data, we coded an individual's dummy for belief in an after-life as 1 if the respondent answered yes to the question "Do you believe in life after death?" For the ISSP data, we coded an individual's dummy as 1 if the respondent answered yes, definitely, or yes, probably, to the question "Do you believe in life after death?" The after-life question was not included in the Gallup Millennium Survey. As before, in the growth regressions, we used only one observation per country for the after-life variable.

${ }^{33}$ The sample of observations was selected to be the same as that used in Table 4.

${ }^{34}$ We again used the functional form $\log [\mathrm{x} /(1-\mathrm{x})]$, where $\mathrm{x}$ is now the fraction of persons who expressed a belief in God. For the WVS data, we coded an individual's belief-in-God dummy as 1 if the respondent answered yes to the question "Do you believe in God?" For the ISSP data, we coded an individual's dummy as 1 if the respondent selected any of the following: "I know God really exists and I have no doubts about it;" "While I have doubts, I feel that I do believe in God;" "I find myself believing in God some of the time, but not at others;" and "I don't believe in a personal God, but I do believe in a Higher Power of some kind." (Results were similar if we used a more stringent definition of belief in God from the ISSP surveys.) The survey responses from the Gallup Millennium Survey were not used here in order to select a sample that was the same as that used in Table 4. As before, in the growth regressions, we used only one observation per country for the belief-in-God variable.
} 
mean of the fraction of persons who expressed a belief in God in the full sample is $80 \%$ (see Table 3), much higher than the other beliefs (averages of $38 \%$ for hell, $55 \%$ for heaven, and $58 \%$ for an after-life). ${ }^{35}$ Hence, the professed belief in God may signify little about the religious convictions that matter for economic performance.

The results are also weak if we substitute for the belief variables a measure of whether persons consider themselves to be religious. ${ }^{36}$ In a specification parallel to those in columns 1 and 3 of Table 4, the estimated coefficients are $-0.0026(0.0026)$ on the monthly attendance variable and $-0.0059(0.0032)$ on the religiousness variable. ${ }^{37}$ Thus, religiousness seems to behave more like monthly church attendance and less like beliefs in hell, heaven, or an after-life.

Columns 5 and 6 of Table 4 show the results when the variables based on belief in hell and heaven are entered simultaneously into the growth equations, along with the monthly attendance variable. The two belief variables have a high sample correlation, 0.90, so our expectation was that it would be difficult to distinguish the two in growth regressions. ${ }^{38}$ However, when the religion shares are excluded from the growth equations in column 5, the results favor belief in hell as a determinant of growth. The estimated coefficient is significantly positive, $0.0104(0.0040)$, whereas that for heaven is close to zero, $-0.0012(0.0040)$. However, a test for equality of the two coefficients has a high p-

\footnotetext{
${ }^{35}$ These values are unweighted means across the country-time observations in the sample.

${ }^{36} \mathrm{We}$ again used the functional form $\log [\mathrm{x} /(1-\mathrm{x})]$, where $\mathrm{x}$ is now the fraction of persons who consider themselves to be a religious person. For the $W V S$ data, we coded an individual's religiousness dummy as 1 if the respondent answered yes to the question "Independently of whether you go to church or not, would you say you are a religious person?" For the ISSP data, we coded the dummy as 1 if the respondent selected any of the following: "Would you describe yourself as 1 . extremely religious, 2 . very religious, or 3. somewhat religious?" As before, in the growth regressions, we used only one observation per country for the religiousness variable.

${ }^{37}$ Because of missing data on the religiousness variable, the number of countries included here was 40 , and the total number of observations was 115 .

${ }^{38}$ The correlations of the monthly attendance variable with the hell and heaven measures are lower: 0.75 and 0.81 , respectively.
} 
value, 0.12 , so that there is only weak statistical evidence that the stick represented by the avoidance of hell provides a better incentive for growth than the carrot embedded in the potential for heaven. The church attendance variable is again significantly negative, $-0.0092(0.0020)$. The three variables (based on belief in hell and heaven and monthly attendance) are jointly significant, with a p-value of 0.000 .

The seven religion shares are again jointly significant when added to the growth equations in column 6 . The preference for the hell variable over the heaven one still appears - the estimated coefficients are $0.0174(0.0083)$ and $0.0039(0.0068)$, respectively. The $\mathrm{p}$-value for a test of equality of these two coefficients is now 0.13 . The monthly attendance variable is again negative and significant, $-0.0154(0.0046)$, and the three variables together are significant with a p-value of 0.002 .

Another extension is to consider whether the connection between religious belief and economic performance depends on the underlying religious doctrine. For example, hell represents a final state in Christianity and Islam but only a temporary setback along the road to enlightenment in Hinduism and Buddhism. Given these doctrinal differences, we would expect belief in hell to matter less for economic outcomes among Hindus and Buddhists than among Christians. We test for this type of effect by modifying the systems in columns 1 and 2 of Table 4 to allow for two coefficients on the belief-in-hell variable. The first coefficient applies to belief in hell interacted with the fraction of the population that adheres to Hinduism or eastern religions (including Buddhist), and the second applies to belief in hell interacted with the remaining fraction of the population.

The results for this extension to column 1 of Table 4 are that the estimated coefficients for the belief-in-hell variable are $0.0059($ s.e. $=0.0101)$ when interacted with 
the Hindu and eastern religion population shares and $0.0090(0.0025)$ when interacted with the remaining population share. Although this pattern-a smaller effect from belief in hell among adherents of Hinduism and eastern religions - accords with our hypothesis, the two estimated coefficients are not statistically significantly different from each other $(p$-value $=0.76)$. If we carry out this analysis as an extension to column 2 of the table (which includes the religion shares in the growth equations), we get $0.0136(0.0185)$ for the first group and $0.0140(0.0054)$ for the second. These estimated coefficients are clearly not significantly different from each other ( $p$-value $=0.98$ ). The main problem is that we lack enough observations from countries with substantial representation among Hinduism and eastern religions to get reliable estimates of coefficients for this group. The 2001 wave of the World Values Survey may help here, because it includes increased representation of East Asian countries.

As already mentioned, church attendance is highly correlated with the religious beliefs - the correlation of the monthly-church-attendance variable with the belief variables is 0.75 for hell and 0.81 for heaven. The attendance and belief variables also have similar sample standard deviations (see Table 3). Therefore, if we consider cases in Table 4, such as columns 1 and 2, where the estimated coefficients on the two religiosity variables are of similar magnitude but opposite sign, the results suggest that being more or less religious overall would not have a strong relationship with economic growth. That is, if church attendance and religious beliefs move together in the usual fashion, the overall relation with economic growth tends to be weak.

One way to bring out this result is to estimate systems in which church attendance or beliefs, but not both, appear in the regressions. If we include the variable for monthly 
church attendance by itself and otherwise use the specification from column 1 of Table 4 , the estimated coefficient is negative, but less than half the magnitude found before: $-0.0039(0.0015)$. If we include the belief-in-hell variable by itself and otherwise use the same specification, the estimated coefficient is positive but insignificantly different from zero: $0.0033(0.0023)$. For the comparable specification with the belief-in-heaven variable by itself, the estimated coefficient is close to zero: $-0.0003(0.0023)$. Therefore, if we had not included simultaneously a measure of attendance and a measure of belief, we would not have found much relationship between religiosity and economic growth. To put it another way, the main estimated growth effect is a positive response to an increase in believing relative to belonging (or attending).

The extreme of believing being high relative to belonging would be "believing without belonging," which is Davie's (1994) characterization of modern Britain. In the international survey data, Britain is not as extreme as Davie suggests - in the 1990 World Values Survey, the fraction of persons who attend church at least monthly is 0.24 , the fraction who believe in heaven is 0.61 , and the fraction who believe in hell is 0.29 . By way of comparison, the respective sample means from the $1990 \mathrm{WVS}$ are $0.36,0.53$, and 0.32. Thus, Britain is only moderately higher than average for beliefs relative to church attendance. More striking patterns of relatively high beliefs appear in some of the Scandinavian countries and Japan—values from the 1990 WVS of monthly church attendance, belief in heaven, and belief in hell are $(0.11,0.55,0.27)$ in Finland, $(0.13$, $0.44,0.19)$ in Norway, $(0.09,0.57,0.12)$ in Iceland, and $(0.14,0.43,0.32)$ in Japan.

Figures 4-7 depict partial relations between the rate of economic growth and the variables that measure monthly church attendance, belief in hell, and belief in heaven. 
Figures 4 and 5 are computed from the estimates shown in column 1 of Table 4 , and

Figures 6 and 7 come from the estimates shown in column 3. The graphs are constructed to hold constant the influence on economic growth from all of the explanatory variables other than the one shown on the horizontal axis. ${ }^{39}$ These kinds of diagrams are particularly useful for seeing whether relationships look linear or are driven by outliers.

Note that Figure 4 shows the negative effect on growth of monthly church attendance while holding constant the belief in hell, whereas Figure 6 shows the negative effect on growth from monthly church attendance while holding fixed the belief in heaven. Figures 5 and 7 show the positive effects on growth from the belief variableshell and heaven, respectively — while holding fixed monthly attendance. Thus, the figures represent the effect on economic growth not from an overall change in religiosity but, rather, from a shift in belonging with believing held fixed or vice versa.

\section{Summary of Main Findings}

Our empirical work used a cross-country panel that includes country level information on church attendance and religious beliefs. These data derive from individual information collected in six international surveys between 1981 and 1999.

Although religiosity tends to decline overall with economic development, the partial relations depend on the specific dimensions of development. For example, the measures of religiosity are positively related to education, negatively related to

\footnotetext{
${ }^{39}$ To calculate the value plotted on the vertical axis, we took the growth rate of per capita GDP (the dependent variable) over any of the three time periods used in Table 4 and subtracted the estimated effect of all of the explanatory variables aside from the one plotted on the horizontal axis. We then normalized the resulting value to have a zero mean - hence, the average value of the variable on the vertical axis is not meaningful. The line shown in each diagram is a least-squares fit between the variable on the vertical axis and the one on the horizontal axis.
} 
urbanization, and positively related to the presence of children. Increased life expectancy tends to be negatively related with church attendance but positively related to religious beliefs.

The presence of a state religion is positively related to the religiosity measures, probably because of the subsidies that typically flow to the established religions. However, religiosity is negatively associated with government regulation of the religion market and with the religious oppression that accompanied the presence of a Communist government. The elimination of Communist regimes led to a recovery of religiosity in most of these countries during the 1990s. In subsequent work, we plan to clarify these linkages by using Fox and Sandler's (2003) Religion and State data set to get direct measures of government subsidy and suppression of religion.

Greater religious pluralism, measured by the diversity of adherence among major religions, is associated with higher church attendance and beliefs. Across the religions, attendance at religious services is higher for Catholic than for the other religions, except for Muslim. The beliefs in heaven and hell tend to be highest for Muslim, then Catholic, then the other faiths.

The analysis of the determinants of religiosity allows us to construct a set of instrumental variables to use to estimate the effects of religion on economic growth. The results show that, for given religious beliefs, increases in church attendance tend to reduce economic growth. In contrast, for given church attendance, increases in some religious beliefs - notably in hell, heaven, and an after-life - tend to increase economic growth. There is also some indication that the stick represented by the fear of hell is more potent for growth than the carrot from the prospect of heaven. 
We should stress that these patterns of growth effects apply when we control for reverse causation by using the instrumental variables suggested by our analysis of the determinants of religiosity. The instruments are the existence of a state religion, the presence of government regulation of religion, the extent of religious pluralism, and the composition of adherence among the main religions. The results remain intact when we enter the composition of religions directly into the growth equations. Based on the arguable exogeneity of the instrumental variables, we think that our estimates reflect causal influences from religion to economic growth, rather than the reverse.

Our conjecture is that higher religious beliefs stimulate growth because they help to sustain aspects of individual behavior that enhance productivity. In subsequent research, we plan to make these channels explicit by studying the linkages between religious beliefs and specific individual characteristics, such as thrift, work ethic, honesty, and openness to strangers. We will measure these characteristics by using survey responses from the World Values Survey.

We think that higher church attendance depresses growth because it signifies a larger use of resources by the religion sector, and the main output of this sector (the religious beliefs) has already been held constant. The results do not mean that greater church attendance has a net negative influence on growth — this net effect depends on the extent to which a rise in attendance leads to greater beliefs, which encourage growth. Thus, another interesting extension would be to attempt to estimate the influence of church attendance on religious beliefs.

We mentioned that church attendance might also measure the social capital built up through organized religion. We also noted that church attendance could proxy for the 
influence of organized religion on laws and regulations that affect economic behavior. Our results indicate that, for given religious beliefs, the overall effect from greater church attendance is to reduce economic growth. This overall effect combines the resources used up by the religion sector, the social-capital aspect of this sector, and the influence of organized religion on laws and regulations. In subsequent research, we plan to use Fox and Sandler's (2003) measures of religious based laws and regulations to sort out these effects from organized religion.

Our future research plans include an assessment of the effects of religiosity on political and social variables, including democracy, the rule of law, fertility, and health. We will also extend our analysis of religiosity at a country-wide level to the behavior of individuals. 


\section{References}

Azzi, C. and R. Ehrenberg (1975). "Household Allocation of Time and Church Attendance," Journal of Political Economy, February, 27-56.

Barrett, D.B. (1982). World Christian Encyclopedia, $1^{\text {st }}$ ed., Oxford, Oxford U. Press.

Barrett, D.B., G.T. Kurian, and T.M. Johnson (2001). World Christian Encyclopedia, $2^{\text {nd }}$ ed., Oxford, Oxford University Press.

Barro, R.J. (1991). “Economic Growth in a Cross Section of Countries," Quarterly Journal of Economics, May, 407-443.

Barro, R.J. (2000). "Inequality and Growth in a Panel of Countries," Journal of Economic Growth, March, 5-32.

Barro, R.J. and J.W. Lee (2001). "International Data on Educational Attainment: Updates and Implications," Oxford Economic Papers, 541-563.

Barro, R.J. and X. Sala-i-Martin (2003). Economic Growth, $2^{\text {nd }}$ edition, MIT Press, forthcoming.

Berger, P.L. (1967). The Sacred Canopy: Elements of a Sociological Theory of Religion, Garden City, Doubleday.

Chaves, M. (1994). "Secularization as Declining Religious Authority," Social Forces, March, 749-774.

Chaves, M. and D.E. Cann (1992). "Regulation, Pluralism, and Religious Market Structure," Rationality and Society, July, 272-290.

Chaves, M. and P.S. Gorski (2001). "Religious Pluralism and Religious Participation," Annual Review of Sociology, 261-281. 
Davie, G. (1994). Religion in Britain since 1945: Believing without Belonging, Oxford, Blackwell.

Finke, R. and L.R. Iannaccone (1993). “Supply-Side Explanations for Religious Change," The Annals of the American Academy of Political and Social Sciences, May, 27-39.

Finke, R. and R. Stark (1992). The Churching of America 1776-1990, New Brunswick, Rutgers University Press.

Fox, J. and S. Sandler (2003). "Separation of Religion and State in the $21^{\text {st }}$ Century: Comparing the Middle East and Western Democracies," presented at the International Studies Association conference, Portland OR, February.

Heston, A., R. Summers, and B. Aten (2002). Penn World Tables Version 6.1, Center for International Comparisons at the University of Pennsylvania (CICUP), October.

Huntington, S.P. (1996). The Clash of Civilizations and the Remaking of World Order, New York, Simon \& Schuster.

Iannaccone, L.R. (1991). “The Consequences of Religious Market Structures: Adam Smith and the Economics of Religion," Rationality and Society, April, 156-177. Inglehart, R. and W.E. Baker (2000). "Modernization, Cultural Change, and the Persistence of Traditional Values," American Sociological Review, February, $19-51$.

Landes, D.S. (1999). The Wealth and Poverty of Nations: Why Some Are so Rich and Some So Poor, New York, Norton.

Martin, D. (1978). A General Theory of Secularization, Oxford, Basil Blackwell. McCleary, R.M. (2003). "Salvation, Damnation, and Economic Incentives," PRPES 
working paper no. 24, available at www.wcfia.harvard.edu/religion, February.

Putnam, R. (2000). Bowling Alone: The Collapse and Revival of American Community, New York, Simon and Schuster.

Sacerdote, B. and E.L. Glaeser (2001). "Education and Religion, National Bureau of Economic Research, working paper no. 8080, January.

Smith, A. (1791). An Inquiry into the Nature and Causes of the Wealth of Nations, $6^{\text {th }}$ ed., London, Strahan.

Stark, R. and W.S. Bainbridge (1987). A Theory of Religion, New York, Lang.

Summers, R. and A. Heston (1991). “The Penn World Table (Mark 5): An Expanded Set of International Comparisons, 1950-1988," Quarterly Journal of Economics, May, 327-369.

Voas, D., D.V.A. Olson, and A. Crockett (2002). "Religious Pluralism and Participation: Why Previous Research Is Wrong,” American Sociological Review, 67, April, 212-230.

Weber, M. (1930). The Protestant Ethic and the Spirit of Capitalism, London, Allen \& Unwin.

Wilson, B. (1966). Religion in Secular Society: A Sociological Comment, London, Watts.

World Bank (2002). World Development Indicators 2002, The World Bank, Washington DC. 


\begin{tabular}{|l|c|c|c|l|c|c|c|}
\hline \multicolumn{7}{|c|}{ Table 1 } \\
\hline \multicolumn{2}{|c|}{ State Religion, State Regulation of Religion, and Religious Pluralism } \\
\hline Country & $\begin{array}{l}\text { State } \\
\text { relig. }\end{array}$ & $\begin{array}{c}\text { State } \\
\text { regulation }\end{array}$ & $\begin{array}{c}\text { Plural } \\
\text { index }\end{array}$ & Country & $\begin{array}{c}\text { State } \\
\text { relig. }\end{array}$ & $\begin{array}{c}\text { State } \\
\text { regulation }\end{array}$ & $\begin{array}{c}\text { Plural } \\
\text { index }\end{array}$ \\
\hline Cameroon & 0 & 0 & 0.73 & Cyprus & 0 & 0 & 0.36 \\
\hline Ghana & 0 & 0 & 0.72 & Denmark & 1 & 0 & 0.02 \\
\hline S. Africa & 0 & 0 & 0.63 & Finland & 1 & 1 & 0.03 \\
\hline Canada & 0 & 0 & 0.56 & France & 0 & 1 & 0.17 \\
\hline Dom. Rep. & 1 & 0 & 0.05 & W. Germany & 0 & 0 & 0.54 \\
\hline Mexico & 0 & 0 & 0.05 & Greece & 1 & 1 & 0.04 \\
\hline U.S. & 0 & 0 & 0.64 & Hungary & 0 & 1 & 0.47 \\
\hline Argentina & 1 & 1 & 0.13 & Iceland & 1 & 0 & 0.03 \\
\hline Brazil & 0 & 0 & 0.20 & Ireland & 1 & 0 & 0.08 \\
\hline Chile & 0 & 0 & 0.22 & Italy & 1 & 1 & 0.01 \\
\hline Colombia & 1 & 0 & 0.05 & Netherlands & 0 & 0 & 0.53 \\
\hline Peru & 1 & 1 & 0.09 & Norway & 1 & 1 & 0.01 \\
\hline Uruguay & 0 & 0 & 0.14 & Poland & 0 & 0 & 0.19 \\
\hline Venezuela & 1 & 1 & 0.08 & Portugal & 1 & 0 & 0.02 \\
\hline Bangladesh & 1 & 1 & 0.24 & Spain & 1 & 0 & 0.00 \\
\hline China & 0 & 1 & 0.46 & Sweden & 1 & 1 & 0.08 \\
\hline Hong Kong & 0 & 0 & 0.60 & Switzerland & 0 & 0 & 0.51 \\
\hline India & 0 & 0 & 0.31 & Turkey & 0 & 1 & 0.01 \\
\hline Israel & 1 & 0 & 0.19 & U.K. & 1 & 1 & 0.33 \\
\hline Japan & 0 & 0 & 0.46 & Australia & 0 & 0 & 0.51 \\
\hline S. Korea & 0 & 0 & 0.33 & New Zealand & 0 & 0 & 0.37 \\
\hline Malaysia & 1 & 0 & 0.68 & Bulgaria & 0 & 0 & 0.28 \\
\hline Pakistan & 1 & 0 & 0.06 & Czech Rep. & 0 & 1 & 0.43 \\
\hline Philippines & 0 & 0 & 0.28 & Estonia & 0 & 1 & 0.48 \\
\hline Singapore & 0 & 0 & 0.63 & Latvia & 0 & 1 & 0.68 \\
\hline Taiwan & 0 & 0 & 0.58 & Lithuania & 0 & 1 & 0.13 \\
\hline Thailand & 1 & 1 & 0.14 & Romania & 0 & 0 & 0.40 \\
\hline Austria & 0 & 0 & 0.15 & Russia & 0 & 1 & 0.51 \\
\hline Belgium & 0 & 0 & 0.05 & Slovak Rep. & 0 & 1 & 0.34 \\
\hline & & & & Slovenia & 0 & 0 & 0.12 \\
\hline
\end{tabular}




\section{Notes to Table 1}

The presence of a state religion (value 1 for the dummy variable) refers to the situation around 1970, as designated by Barrett, Kurian, and Johnson (2001, pp. 834-35). We assigned the value one only if Barrett, et al, designated an individual religion, not if they classified the state as favoring religion in general. State regulation (value 1) refers to a situation in which the state appoints or approves church leaders. This designation comes from discussions in Barrett (1982) and Barrett, Kurian, and Johnson (2001) and elsewhere and typically applies during the late 1970s. The pluralism index is one minus the Herfindahl index based on the fractions of adherents in 1980 to nine major religions, among persons expressing adherence to some religion. The religions are Catholic, Muslim, Protestant, Hindu, Buddhist, other eastern religions, Jewish, Orthodox, and other. These data are from Barrett (1982). For the Eastern European countries shown at the end of the table, the data are from Barrett, Kurian, and Johnson (2001) and apply in 1990. The countries shown are the ones included in the subsequent statistical analysis (as dictated by data availability). 


\begin{tabular}{|c|c|c|c|}
\hline \multicolumn{4}{|c|}{$\begin{array}{l}\text { Table } 2 \\
\end{array}$} \\
\hline \multicolumn{4}{|c|}{ Church Attendance and Religious Beliefs } \\
\hline \multicolumn{4}{|c|}{ (cells show estimated coefficients with standard errors in parentheses) } \\
\hline & \multicolumn{3}{|c|}{ dependent variable } \\
\hline & (1) & (2) & (3) \\
\hline explanatory variable & $\begin{array}{l}\text { monthly } \\
\text { church } \\
\text { attendance }\end{array}$ & $\begin{array}{l}\text { belief in } \\
\text { heaven }\end{array}$ & $\begin{array}{l}\text { belief in } \\
\text { hell }\end{array}$ \\
\hline Log of per capita GDP & $0.04(0.16)$ & $-0.28(0.21)$ & $-0.28(0.18)$ \\
\hline Years of education & $0.192(.036)$ & $0.253(.040)$ & $0.234(.038)$ \\
\hline Urbanization rate & $-1.49(0.34)$ & $-1.65(0.43)$ & $-2.11(0.41)$ \\
\hline 1/(life expectancy at age 1$)$ & $2.2(1.2)$ & $-3.5(2.0)$ & $-2.5(1.7)$ \\
\hline Population share $>65$ & $0.3(3.2)$ & $-9.8(4.8)$ & $-12.5(4.2)$ \\
\hline Population share $<15$ & $5.5(2.0)$ & $4.9(2.9)$ & $1.5(2.6)$ \\
\hline Religious pluralism & $1.35(0.32)$ & $1.24(0.38)$ & $1.13(0.37)$ \\
\hline State religion & $0.87(0.14)$ & $1.07(0.18)$ & $0.79(0.17)$ \\
\hline Regulation of religion & $-0.64(0.11)$ & $-0.36(0.13)$ & $-0.12(0.13)$ \\
\hline Communist regime & $-0.69(0.21)$ & $-0.77(0.24)$ & $-0.88(0.23)$ \\
\hline Ex-Communist (in 1995) & $0.20(0.19)$ & $0.43(0.23)$ & $0.79(0.21)$ \\
\hline Ex-Communist (in 1998) & $0.33(0.16)$ & $0.20(0.16)$ & $0.47(0.17)$ \\
\hline Ex-Communist (in 1999) & $0.59(0.23)$ & -- & -- \\
\hline ISSP data & $-0.17(0.08)$ & $0.10(0.08)$ & $0.35(0.08)$ \\
\hline Gallup data & $-0.01(0.11)$ & -- & -- \\
\hline Eastern religion fraction & $-2.53(0.24)$ & $-1.56(0.30)$ & $-0.85(0.28)$ \\
\hline Hindu fraction & $-0.80(0.48)$ & $-2.05(0.56)$ & $-1.28(0.50)$ \\
\hline Jewish fraction & $-2.75(0.43)$ & $-2.51(0.38)$ & $-1.20(0.41)$ \\
\hline Muslim fraction & $0.26(0.30)$ & $1.94(0.41)$ & $2.55(0.37)$ \\
\hline Orthodox fraction & $-1.83(0.24)$ & $-1.54(0.29)$ & $-0.95(0.30)$ \\
\hline Protestant fraction & $-2.30(0.19)$ & $-1.32(0.24)$ & $-1.46(0.22)$ \\
\hline Other religion fraction & $-0.61(0.89)$ & $3.00(1.10)$ & $1.43(0.99)$ \\
\hline $\begin{array}{l}\text { No. of countries \& total } \\
\text { observations }\end{array}$ & 59,181 & 50,130 & 50,130 \\
\hline $\begin{array}{l}\text { No. of observations for } \\
\text { each equation }\end{array}$ & $\begin{array}{l}22,36,22 \\
32,28,41\end{array}$ & $\begin{array}{l}21,33,16 \\
30,30\end{array}$ & $\begin{array}{c}21,33,16 \\
30,30\end{array}$ \\
\hline $\begin{array}{l}\text { R-squared for each } \\
\text { equation }\end{array}$ & $\begin{array}{l}.87, .77, .80 \\
.89, .84, .74\end{array}$ & $\begin{array}{c}.69, .79, .90 \\
.85, .84\end{array}$ & $\begin{array}{c}.77, .75, .71 \\
86, .71\end{array}$ \\
\hline
\end{tabular}




\section{Notes to Table 2}

Each system, numbered (1)-(3), consists of five or six equations, corresponding to observations for countries on the dependent variables at five or six points in time: 198184, subsequently called WVS81 (World Values Survey data mostly for 1981, supplemented by information from Gallup surveys for a few countries); 1990-93, subsequently called WVS90 ( $W V S$ data mostly for 1990, plus observations on some variables for Greece in 1987 from Eurodim); 1990-93, subsequently called ISSP91 (International Social Survey Programme data mostly for 1991); 1995-97, subsequently called WVS95 (WVS data mostly for 1995 or 1996); 1998-2000, subsequently called ISSP98 (ISSP data mostly for 1998); and 1999 (Gallup Millennium Survey). The last source has data only for weekly and monthly church attendance and belief in God. The dependent variables are population averages of monthly church attendance in column 1 , belief in heaven in column 2, and belief in hell in column 3. The measured value is either the fraction of people attending or the fraction who hold the belief. For example, in column 1, monthly church attendance is observed for 23 countries with 1981 data, 36 countries with 1990 data, 22 countries with 1991 data, 32 countries with 1995 data, 28 countries with 1998 data, and 41 countries with 1999 data.

The form of each dependent variable used in the regressions is $\log [\mathrm{x} /(1-\mathrm{x})]$, where $\mathrm{x}$ is the fraction of persons attending or believing. This form confines fitted values of $\mathrm{x}$ to the interval $(0,1)$.

Explanatory variables and data sources: The log of real per capita GDP, average years of schooling of adults aged 25 and older, the urbanization rate, the reciprocal of life expectancy at age one, and the shares of the population aged over 65 and under 15 are observed just prior to the dependent variable. For example, 1980 per capita GDP is matched with the dependent variables for 1981, 1990 per capita GDP with the dependent variables for 1990 and 1991, and 1995 per capita GDP with the dependent variables for 1995, 1998, and 1999. Because of missing data for 1990, GDP data for 1995 are used for Bulgaria and Russia in the systems for WVS90 and ISSP91. Because of missing data for 1995, GDP data for 1990 are used for West Germany in the systems for WVS95 and ISSP98.

The national-accounts data are from Heston, Summers, and Aten (2002). Education data are from Barro and Lee (2001). Most other economic and social variables are from World Bank (2002). Religious pluralism (1 minus the Herfindahl index of religion shares for nine groups among those professing some religion) is for 1980 (1990 for some Eastern European countries) using data from Barrett (1982) and Barrett, Kurian, and Johnson (2001). The dummy variable for the presence of a state religion (from Barrett, Kurian, and Johnson [2001]) applies in 1970. The dummy variable for state regulation of religion (based on whether the state appoints or approves church leaders, from Barrett [1982] and Barrett, Kurian, and Johnson [2001]) is for the 1970s. The dummy for the presence of a Communist regime applies to the pre- 1990 period. The 1995 and later equations also include a dummy for whether the country had been Communist but is no longer Communist. For example, in the 1995 equations, the total 
effect for a former Communist country equals the coefficient on the Communist dummy plus the coefficient on the ex-Communist (in 1995) dummy. The dummy for the use of ISSP data applies to the 1991 and 1998 equations and that for Gallup applies to the 1999 equation. The religion variables are the fractions adhering to each religion in 1980 (1990 for some Eastern European countries), according to Barrett (1982) and Barrett, Kurian, and Johnson (2001). The Catholic fraction is omitted as a normalization in each case; hence, the coefficient on each religion represents the differential effect between that religion and Catholic. For Israel, the ISSP 1991-93 surveys covered only the Jewish population; hence, the religion shares in this case equal one for Jewish and zero for the others.

Estimation: Each system is estimated by the seemingly-unrelated (SUR) method, which allows the error terms to be correlated over the time periods for each country. This procedure allows for the inclusion of multiple observations for a single country but recognizes that these observations tend not to be independent. For example, in system 1, the error term for a country's 1981 monthly church attendance is allowed to be correlated with those for the other periods. This procedure does not weight countries differentially for size or other characteristics. Constant terms, not shown, are included for each system. The constants vary by system but not across the equations within a system.

Statistics: The table shows the estimated coefficient of each variable. The value shown in parentheses is the standard error of each coefficient estimate. The table also shows the number of countries included in each equation of a system, the total number of observations, and the number of observations and R-squared values for each of the five or six equations of a system. 


\begin{tabular}{|c|c|c|}
\hline \multicolumn{3}{|c|}{ Table 3} \\
\hline \multicolumn{3}{|c|}{ Means and Standard Deviations of Variables } \\
\hline Variable & Mean & Standard deviation \\
\hline Weekly church attendance & 0.24 & 0.21 \\
\hline Monthly church attendance & 0.36 & 0.23 \\
\hline Belief in heaven & 0.55 & 0.22 \\
\hline Belief in hell & 0.38 & 0.21 \\
\hline Belief in after-life & 0.58 & 0.17 \\
\hline Belief in God in some form & 0.80 & 0.14 \\
\hline Religious person & 0.61 & 0.20 \\
\hline \multicolumn{3}{|l|}{$\log [x /(1-x)]$ for: } \\
\hline monthly attendance & -0.74 & 1.20 \\
\hline belief in heaven & 0.33 & 1.15 \\
\hline belief in hell & -0.55 & 1.06 \\
\hline Log of per capita GDP & 9.37 & 0.69 \\
\hline Years of education (years) & 8.29 & 2.11 \\
\hline Urbanization rate & 0.70 & 0.15 \\
\hline Life expectancy at age 1 (years) & 74.1 & 4.1 \\
\hline 1/(life expect. at age 1) (x 100) & 1.35 & 0.084 \\
\hline Population share $>65$ & 0.112 & 0.041 \\
\hline Population share $<15$ & 0.238 & 0.073 \\
\hline Religious pluralism & 0.29 & 0.23 \\
\hline State religion & 0.33 & 0.47 \\
\hline Regulation of religion & 0.37 & 0.48 \\
\hline Communist regime & 0.23 & 0.42 \\
\hline Catholic fraction & 0.46 & 0.40 \\
\hline Eastern religion fraction & 0.073 & 0.240 \\
\hline Hindu fraction & 0.012 & 0.086 \\
\hline Jewish fraction & 0.015 & 0.099 \\
\hline Muslim fraction & 0.043 & 0.147 \\
\hline Orthodox fraction & 0.077 & 0.211 \\
\hline Protestant fraction & 0.29 & 0.34 \\
\hline Other religion fraction & 0.022 & 0.067 \\
\hline Non-religious fraction & 0.107 & 0.123 \\
\hline
\end{tabular}

Note: The columns show the (unweighted) means and standard deviations of the variables used in the statistical analysis of Table 2, along with some other variables. The sample for most variables is the set of observations for which data are available for church attendance or belief in heaven and for the explanatory variables used in Table 2. For the religious belief variables, the set of observations is smaller. The religion fractions, aside from non-religious, are relative to the population of adherents to some religion. 
Table 4

Regressions for Economic Growth

\begin{tabular}{|c|c|c|c|c|c|c|}
\hline \multicolumn{7}{|c|}{ (standard errors of coefficients are in parentheses) } \\
\hline & (1) & (2) & (3) & (4) & (5) & (6) \\
\hline $\begin{array}{l}\text { Explanatory } \\
\text { variable: }\end{array}$ & & & & & & \\
\hline $\begin{array}{l}\text { (a group of other } \\
\text { variables is included } \\
\text { but not shown) }\end{array}$ & & & & & & \\
\hline $\begin{array}{l}\text { Monthly church } \\
\text { attendance }\end{array}$ & $\begin{array}{l}-0.0095 \\
(0.0018)\end{array}$ & $\begin{array}{l}-0.0156 \\
(0.0044)\end{array}$ & $\begin{array}{l}-0.0104 \\
(0.0023)\end{array}$ & $\begin{array}{l}-0.0123 \\
(0.0043)\end{array}$ & $\begin{array}{l}-0.0092 \\
(0.0020)\end{array}$ & $\begin{array}{l}-0.0154 \\
(0.0046)\end{array}$ \\
\hline Belief in hell & $\begin{array}{c}0.0094 \\
(0.0025)\end{array}$ & $\begin{array}{c}0.0140 \\
(0.0058)\end{array}$ & -- & -- & $\begin{array}{c}0.0104 \\
(0.0040) \\
\end{array}$ & $\begin{array}{r}0.0174 \\
(0.0083) \\
\end{array}$ \\
\hline Belief in heaven & -- & -- & $\begin{array}{c}0.0069 \\
(0.0029)\end{array}$ & $\begin{array}{c}0.0076 \\
(0.0048)\end{array}$ & $\begin{array}{l}-0.0012 \\
(0.0040)\end{array}$ & $\begin{array}{c}0.0039 \\
(0.0068)\end{array}$ \\
\hline $\begin{array}{l}\text { Eastern religion } \\
\text { share }\end{array}$ & -- & $\begin{array}{l}-0.010 \\
(0.011)\end{array}$ & -- & $\begin{array}{c}0.003 \\
(0.009) \\
\end{array}$ & -- & $\begin{array}{l}-0.013 \\
(0.012) \\
\end{array}$ \\
\hline Hindu share & -- & $\begin{array}{l}-0.034 \\
(0.016)\end{array}$ & -- & $\begin{array}{l}-0.030 \\
(0.017)\end{array}$ & -- & $\begin{array}{l}-0.040 \\
(0.018)\end{array}$ \\
\hline Jewish share & -- & $\begin{array}{l}-0.004 \\
(0.014)\end{array}$ & -- & $\begin{array}{l}0.006 \\
(0.013)\end{array}$ & -- & $\begin{array}{l}-0.006 \\
(0.015)\end{array}$ \\
\hline Muslim share & -- & $\begin{array}{l}-0.032 \\
(0.015)\end{array}$ & -- & $\begin{array}{l}-0.012 \\
(0.010) \\
\end{array}$ & -- & $\begin{array}{l}-0.034 \\
(0.015)\end{array}$ \\
\hline Orthodox share & -- & $\begin{array}{l}-0.050 \\
(0.021)\end{array}$ & -- & $\begin{array}{l}-0.029 \\
(0.017)\end{array}$ & -- & $\begin{array}{l}-0.051 \\
(0.021)\end{array}$ \\
\hline Protestant share & -- & $\begin{array}{l}-0.015 \\
(0.007)\end{array}$ & -- & $\begin{array}{l}-0.018 \\
(0.008) \\
\end{array}$ & -- & $\begin{array}{l}-0.012 \\
(0.008) \\
\end{array}$ \\
\hline Other religion share & -- & $\begin{array}{l}-0.001 \\
(0.015)\end{array}$ & -- & $\begin{array}{l}-0.001 \\
(0.016)\end{array}$ & -- & $\begin{array}{l}-0.001 \\
(0.015)\end{array}$ \\
\hline $\begin{array}{l}\text { p-value for } \\
\text { attendance } \\
\text { and belief(s) }\end{array}$ & 0.000 & 0.001 & 0.000 & 0.009 & 0.000 & 0.002 \\
\hline $\begin{array}{l}\text { p-value for religion } \\
\text { shares }\end{array}$ & -- & 0.001 & -- & 0.001 & -- & 0.001 \\
\hline $\begin{array}{l}\text { No. of countries and } \\
\text { total observations }\end{array}$ & 41,118 & 41,118 & 41,118 & 41,118 & 41,118 & 41,118 \\
\hline $\begin{array}{l}\text { No. of observations } \\
\text { for each period }\end{array}$ & $\begin{array}{c}38,41 \\
39\end{array}$ & $\begin{array}{c}38,41 \\
39\end{array}$ & $\begin{array}{l}38,41 \\
\quad 39\end{array}$ & $\begin{array}{c}38,41 \\
39\end{array}$ & $\begin{array}{c}38,41 \\
39\end{array}$ & $\begin{array}{l}38,41 \\
39\end{array}$ \\
\hline $\begin{array}{l}\text { R-squared values } \\
\text { for each period }\end{array}$ & $\begin{array}{c}.39, .77 \\
.36\end{array}$ & $\begin{array}{c}.67, .63 \\
.25 \\
\end{array}$ & $\begin{array}{c}.36, .68 \\
.32\end{array}$ & $\begin{array}{c}.66, .60 \\
.36 \\
\end{array}$ & $\begin{array}{c}.39, .78, \\
.35\end{array}$ & $\begin{array}{c}.65, .63, \\
.19 \\
\end{array}$ \\
\hline
\end{tabular}




\section{Notes to Table 4}

Variables: The dependent variables are the growth rates of real per capita GDP over 1965-75, 1975-85, and 1985-95. The explanatory variables that are not shown are the log of per capita GDP in 1965, 1975, and 1985; years of male secondary and higher school attainment in 1965, 1975, and 1985; the reciprocal of life expectancy at age one in 1960, 1970, and 1980; the average ratio over each period of total investment to GDP; the $\log$ of the total fertility rate in 1960,1970, and 1980; the average ratio for each period of exports plus imports to GDP, filtered for the usual relation of this ratio to the logs of population and area; the average ratio for each period of government consumption (net of outlays on defense and education) to GDP; the growth rate of the terms of trade over each period, interacted with the average ratio of exports plus imports to GDP; the average of the Political Risk Services subjective indicator of maintenance of the rule of law (the value for 1982 or 1985 appears in the first two equations); the average for each period of the Freedom House subjective measure of democracy (electoral rights) and its square; and the consumer price inflation rate for each period. Columns 2, 4, and 6 include the shares for the seven religion categories shown. These shares apply to persons expressing adherence to some religion, and the Catholic share is omitted as a normalization. The monthly church attendance and belief variables are entered, as in Table 2 , as $\log [\mathrm{x} /(1-\mathrm{x})]$, where $\mathrm{x}$ is the fraction attending or believing. Separate constants are included for each period. For data sources, see the notes to Table 2.

Estimation: Estimation is by three-stage least squares, using beginning-of-period or lagged values as instruments (except that measures of colonial status appear instead of the lagged inflation rate). The instrument lists exclude the church attendance and belief variables but include the seven religion shares along with the dummy for the presence of a state religion, the dummy for the existence of state regulation of religion, and the pluralism indicator for religious diversity (in 1970 for the first two equations and in 1980 or 1990 for the third equation).

Statistics: The table shows the estimated coefficient of each variable. The value in parentheses is the standard error of each coefficient estimate. The p-values refer to tests of the hypothesis that the coefficients of the church attendance and religious belief variables are jointly zero or that the coefficients of the religion share variables are jointly zero. The R-squared values apply separately to each of the three time periods for economic growth. 
Figure 1

Church Attendance versus GDP (simple relation)

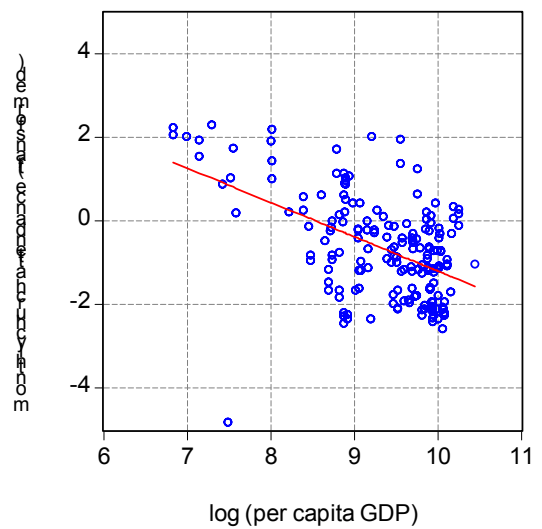

Figure 2

Belief in Heaven versus GDP (simple relation)

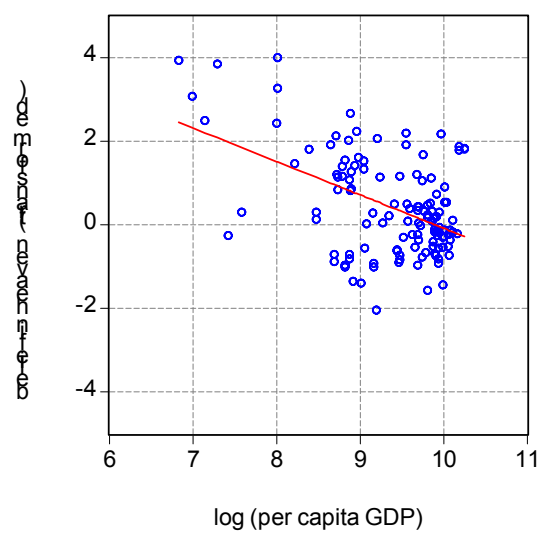

Figure 3

Belief in Hell versus GDP

(simple relation)

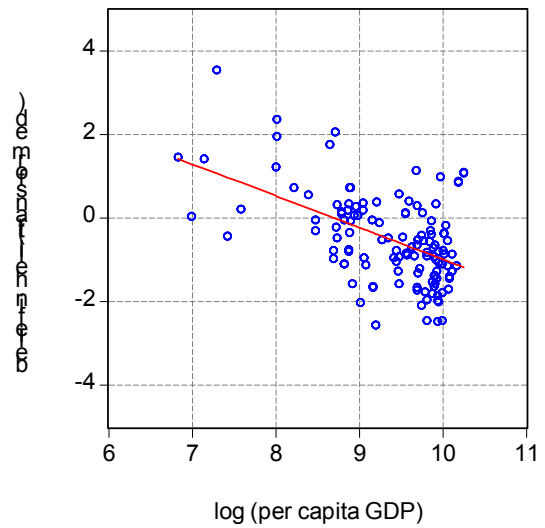


Figure 4

Economic Growth and Church Attendance (belief in hell included)

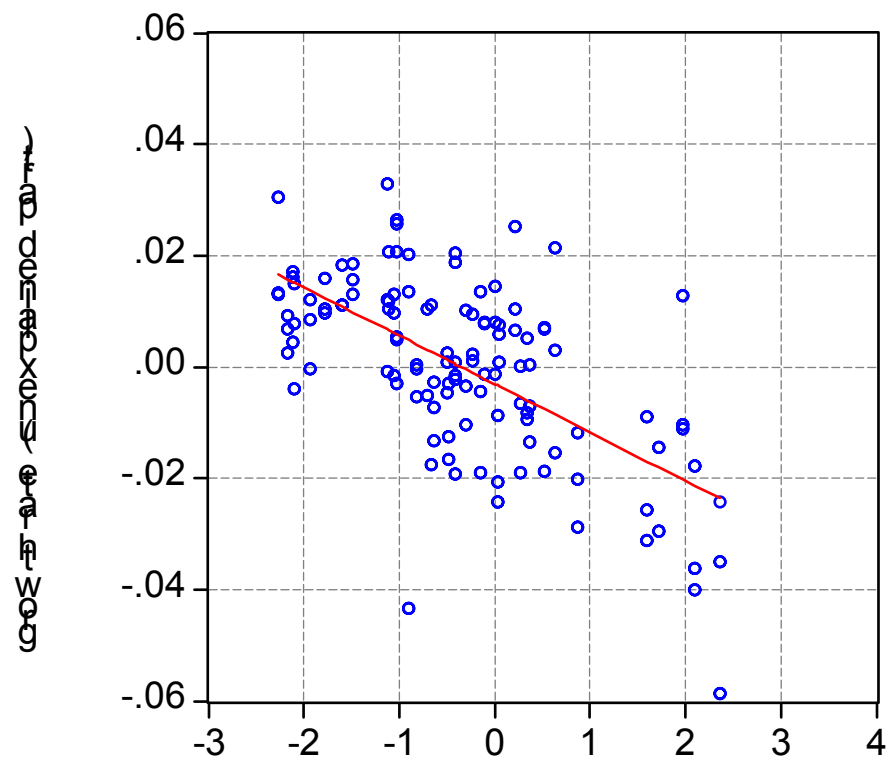

monthly church attendance (transformed)

Figure 5

Economic Growth and Belief in Hell

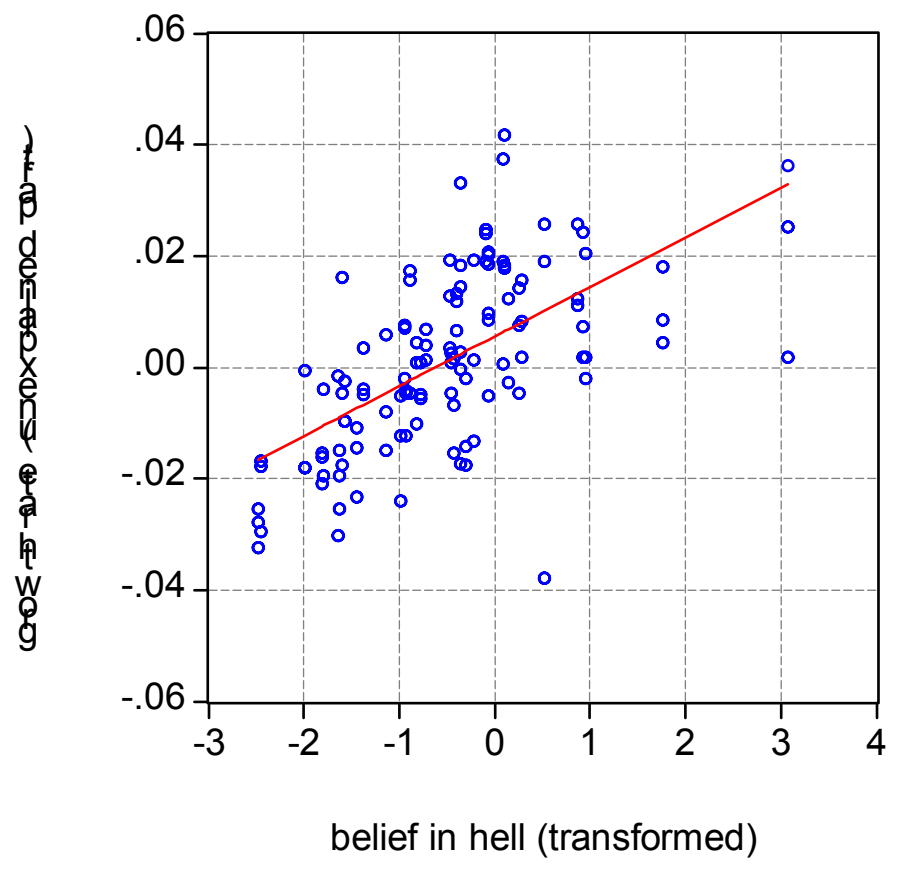


Figure 6

Growth Rate and Church Attendance (belief in heaven included)

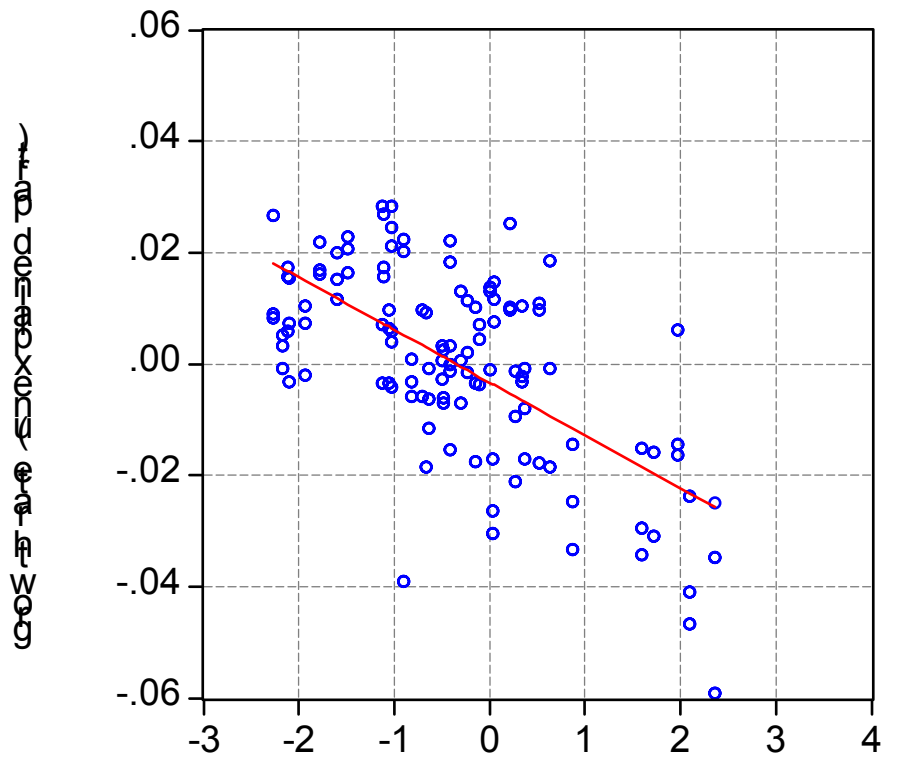

monthly church attendance (transformed)

Figure 7

Growth Rate and Belief in Heaven

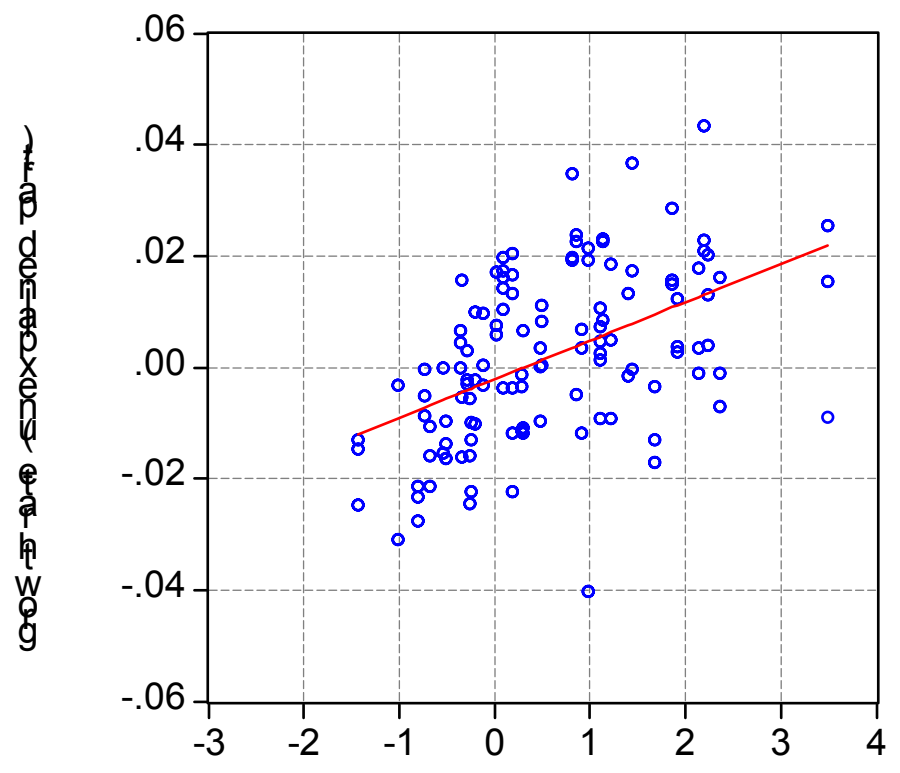

belief in heaven (transformed) 